\title{
Géomorphologie : relief, processus,
}

environnement

vol. 22 - $n^{\circ} 3 \mid 2016$

Niveaux marins du Maroc Atlantique durant le dernier Interglaciaire (SIM 5.5, SIM 5.3 et SIM 5.1)

\section{Sea-level fluctuation during MIS 5e and geomorphological context on the southern coast of the Strait of Gibraltar (Morocco)}

Fluctuation du niveau marin et contexte géomorphologique au cours du MIS $5 e$ au niveau de la côte sud du détroit de Gibraltar (Maroc)

Jamal Eddine El Abdellaoui, François Petit, Bassam Ghaleb and André Ozer

\section{(2) OpenEdition}

\section{Journals}

Electronic version

URL: http://journals.openedition.org/geomorphologie/11467

DOI: 10.4000/geomorphologie.11467

ISSN: 1957-777X

\section{Publisher}

Groupe français de géomorphologie

\section{Printed version}

Date of publication: 21 November 2016

Number of pages: $287-301$

ISBN: 978-2-913282-73-5

ISSN: 1266-5304

\section{Electronic reference}

Jamal Eddine El Abdellaoui, François Petit, Bassam Ghaleb and André Ozer, « Sea-level fluctuation during MIS 5 e and geomorphological context on the southern coast of the Strait of Gibraltar

(Morocco) », Géomorphologie : relief, processus, environnement [Online], vol. 22 - n $3 \mid 2016$, Online since 03 October 2016, connection on 03 May 2019. URL : http://journals.openedition.org/ geomorphologie/11467 ; DOI : 10.4000/geomorphologie.11467 


\title{
Sea-level fluctuation during MIS 5e and geomorphological context on the southern coast of the Strait of Gibraltar (Morocco)
}

\section{Fluctuation du niveau marin et contexte géomorphologique au cours du MIS 5e au niveau de la côte sud du détroit de Gibraltar (Maroc)}

\author{
Jamal Eddine El Abdellaoui* ${ }^{*}$, François Petit ${ }^{\mathrm{b}}$, Bassam Ghaleb ${ }^{\mathrm{c}}$, André Ozer ${ }^{\mathrm{b}}$ \\ ${ }^{a}$ Université Abdelmalek Assaàdi, Faculté des Sciences et Techniques - B.P 416, Tanger, Maroc. \\ bUniversité de Liège, Unité de géographie physique - Bât. B11, Sart Tilman, B4000 Liège, Belgique. \\ 'Université du Québec à Montréal, GEOTOP-UQAM - Montréal-QC, H3C 3P8 Canada.
}

INFORMATION SUR L'ARTICLE

Reçu le 26 avril 2015

Reçu sous sa forme révisée le 20 mars 2016

Définitivement accepté le 13 juillet 2016

*Auteur correspondant. Tél : +212 539393954 Courriels :

j.elabdellaoui@fstt.ac.ma (J.E. El Abdellaoui)

francois.petit@ulg.ac.be (F. Petit)

ghaleb.bassam@uqam.ca (B. Ghaleb)

aozer@ulg.ac.be (A. Ozer)

\begin{abstract}
This work traces the geomorphological and tectonic evolution of the southern coast of the Strait of Gibraltar at the MIS 5e during the last interglacial. Stratigraphic analysis of three marine terraces was achieved. The three studied sections show two transgression-regression cycles. It appears that the lithology and structure of the geological substrate has played a fundamental role in coastal geomorphological evolution during the isotope sub-stage 5e. This sub-stage is characterized by two transgressive pulses of eustatic origin. The U/Th dating of a sample of coral shows that the second pulse has an age of at least $119.6 \pm 2.3 \mathrm{ka}$. The maximum average uplift rate is estimated of $0.085 \mathrm{~m} /$ year over the last $117 \mathrm{kyr}$ for the referenced outcrop. The MIS $5 \mathrm{e}$ has been raised to a height of 13 to $16 \mathrm{~m}$ MSL.
\end{abstract}

Keywords: MIS 5e, marine terraces, geomorphology, isotopic dating, transgressions, uplift rates.

\section{RÉSUMÉ}

Cette étude concerne l'évolution géomorphologique et tectonique de la rive sud du détroit de Gibraltar au MIS $5 e$ au cours du dernier interglaciaire. L'analyse stratigraphique de trois terrasses marines a été réalisée. On retrouve sur les trois coupes étudiées deux cycles de transgression-régression. Il ressort que la lithologie et la structure $d u$ substratum géologique ont joué un rôle primordial dans l'évolution géomorphologique côtière au cours du sous-stade isotopique 5e. Ce dernier est caractérisé par deux pulsations transgressives eustatiques. La datation U/Th d'un fragment de corail montre que la deuxième pulsation est âgée d'au moins 119,6 $\pm 2,3$ ka. Le taux de soulèvement maximum moyen est estimé à $0,085 \mathrm{~mm} / \mathrm{an}$ au cours des $117 \mathrm{ka}$ pour les affleurements de référence. Les dépôts du MIS 5e ont ainsi été soulevés de 7 à $10 \mathrm{~m}$ et portés à une altitude de 13 à $16 \mathrm{~m}$ MSL.

Mots clés : MIS 5e, terrasses marines, géomorphologie, datation isotopique, transgressions, taux de soulèvement.

\section{Introduction}

Isotopic dating on reliable material, and sequence stratigraphy analysis remain a useful tools for understanding the evolution of sedimentary and geomorphological environment, thereby better understanding the nature and causes of sea level fluctuations. We attempt to develop a detailed stratigraphic analysis of three marine terraces sections observed along the southern shore of the Strait of Gibraltar (fig. 1). The goal of this study is to use isotopic dating to estimate the height of the last interglacial sea level, as well as the local uplift rate, via comparison to sections that have been studied in more stable areas.

No consensus exists among Quaternary researchers and paleoclimatologists regarding the temporal boundaries and maximum sea level rise during the Marine Isotope Stage (MIS) 5e. This lack of agreement also extends to the number of sea-level fluctuations and their ages (tab. 1). This divergence is explained by the diversity of the methods and approaches used, by the quality of the data collected and by the specific geologic and paleoclimate history of the study area.

The duration of MIS 5e is also a topic of significant debate (tab. 1). Gallup et al. (1994) suggested that MIS 5e cannot be older than 130 kyr. Muhs et al. (2002) stated that the peak of the last interglacial sea-level highstand occurred between 128 and 114 kyr. Hearty and Neumann (2001) and Hearty et al. (2007) suggested that the period was between 132 and $118 \mathrm{kyr}$. Rohling et al. (2008) determined that MIS 5e occured between 124 and 119 kyr. Blanchon (2011) examined stable areas and concluded that MIS $5 \mathrm{e}$ was between 128 and 116 kyr. Generally, the end of MIS 5e is believed to have occured between 118.5 and $116 \mathrm{kyr}$ (Cutler et al., 2003; Knudsen et al., 2002; Masson-Delmotte et al., 2011).

The MIS 5e highstand sea level varies by location and researcher. A single highstand is supported by some studies such as Choukri et al. (2011) in Agadir, southwest Morocco, Speed and Cheng (2004) in Barbados, Stirling et al. (1998) on west coast of Australia, Jedoui et al. 
Jamal Eddine El Abdellaoui et al.

Tab. 1 - The information Synthesis of the MIS 5e.

Tab. 1 - Synthèse des données sur le MIS $5 e$.

\begin{tabular}{|c|c|c|c|c|}
\hline Area & $\begin{array}{l}\text { Number of } \\
\text { highstand }\end{array}$ & $\begin{array}{c}\text { Sea level } \\
\text { height during } \\
\text { MIS } 5 \mathrm{e}(\mathrm{m})\end{array}$ & $\begin{array}{l}\text { Duration of } \\
\text { MIS } 5 \mathrm{e}(\mathrm{kyr})\end{array}$ & Authors \\
\hline Spain & 2 to 3 & 2 and 6 & $135-117$ & Zazo et al. $(1999,2003)$; Rodriguez-Vidal et al. (2004) \\
\hline Morocco & 1 to 2 & 4 to 6 & & $\begin{array}{c}\text { Choukri et al. (2011) ; Occhietti et al. (1993, 2002) ; Lefevre } \\
\text { et Raynal (2002); El Abdellaoui (2014); Stearns and } \\
\text { Thurber (1965); Brébion et al. (1986); Alouane (1997); } \\
\text { El Kadiri et al. (2010); Cadet et al. (1977); El Gharbaoui } \\
\text { (1977); El Fahssi (1999) }\end{array}$ \\
\hline Tunisia & 1 & 3 to 6 & & Jedoui et al. (2001) \\
\hline Barbados & 1 to 2 & & $128-120$ & Speed and Cheng (2004); Schellmann et al. (2004) \\
\hline Australia (west coast) & 1 & & $128-116$ & Stirling et al. (1998) \\
\hline Mexico & 1 & & $128-116$ & Blanchon et al. (2009) \\
\hline South Africa & 1 & 6 to 8.5 & $138-118 \pm 7$ & Carr et al. (2010) \\
\hline Red sea & 2 & 5 to 9 & $124-119$ & Choukri et al. (2007) ; Rohling et al. (2008) \\
\hline Southern Arabian Gulf & 2 & 6 & & Williams and Walkden (2002) \\
\hline Eritrea & 3 & & & Bruggemann et al. (2004) \\
\hline Bahamas & 3 & 6 to 8.5 & $132-118$ & Hearty and Neumann (2001) \\
\hline North America & & & $128-114$ & Muhs et al. (2002) \\
\hline Reef areas & & 6 & & Blanchon et al. (2009) \\
\hline Word scale & & 6.6 & & Kopp et al. (2009) \\
\hline Word scale & 3 & 6 to 9 & $132-118$ & Hearty et al. (2007) \\
\hline
\end{tabular}

(2001) in Tunisia and Muhs et al. (2002) on the Pacific coast of North America.

Other authors have suggested two highstands separated by a regressive phase. These authors include Choukri et al. (2007) and Rohling et al. (2008) in the Red Sea, Williams and Walkden (2002) in the southern Arabian Gulf, Kindler et al. (1997) in Sardinia, Schellmann et al. (2004) in Barbados, Zazo et al. (2010) in Cape Verde Islands at MIS 5.5, O'Leary et al. (2013) in Western Australia, Blanchon et al. (2009) in Mexico, Carr et al. (2010) in South Africa and El Abdellaoui (2014) at the Atlantique coast of Tangier.

Furthermore, three transgressive pulses are identified by some authors, including Bruggemann et al. (2004) in Eritrea, Hearty and Neumann (2001) in Bahamas, Zazo et al. (2003) in Iberian Peninsula (Almeria, Murcia and Alicante), in the Balearic Islands (Mallorca) and in Canary Islands (the islands of Lanzarote, Fuerteventura and Tenerife) and Hearty et al. (2007) in a world scale synthesis study.

The peak height of the last interglacial sea level also varies spatially. On a global scale, Kopp et al. (2009) found that the peak of the global sea level was probably at $6.6 \mathrm{~m}$ above sea level (ASL) for $95 \%$ of the examined cases. Blanchon (2011) suggested that final highstand peak in reef areas was at $6 \mathrm{~m}$ ASL. Hearty et al. (2007) found that the sea level ranged between 6 and $9 \mathrm{~m}$ at the end of the last interglacial period (120-118 kyr). On a local scale, authors consider that MIS 5e sea level reached $6 \mathrm{~m}$ on northern shore of the Strait of Gibraltar (Zazo et al., 1999, 2003; Rodriguez-Vidal et al., 2004). Along its southern shore, the MIS 5e Achakkar marine terrace is located at 5-6 m ASL (fig. 1; Stearns and Thurber, 1965; Brébion et al., 1986; Alouane, 1997). In Ras-Leona, the MIS 5 terrace is located at 4-5 m (El Kadiri et al., 2010) (fig. 1). Whereas, in stable sector on the Moroccan Atlantic coast (Casablanca) (fig. 1), the MIS 5e terrace is located at $6 \mathrm{~m}$ (Occhietti et al., 1993, 2002; Lefevre and Raynal, 2002).
In addition, authors have identified two to three significant cold periods in the North Sea during MIS 5e. The most pronounced cold period occurred at $124 \mathrm{kyr}$ (Fronval et al., 1998; Hearty and Neuman, 2001). Van Nieuwenhove et al. (2011) identified a cold period at approximately $120.5 \mathrm{kyr}$ and Stirling et al. (1998) identified one at $121 \pm 1 \mathrm{kyr}$. The last warm period is at $120-118 \mathrm{kyr}$ (Fronval et al., 1998; Knudsen et al., 2002). Muhs et al. (2002) placed the peak of the last interglacial period at $120 \mathrm{kyr}$. Blanchon et al. (2009) suggested that the last warm period occurred at $\sim 121 \mathrm{kyr}$. In this study, we consider therefore that the first pulse occurred between 128 and $125 \mathrm{kyr}$ and the second occured between 121 and $118 \mathrm{kyr}$, with a cold period between 124 and $121 \mathrm{kyr}$.

\section{Geological and geomorphological context}

The study area is located at the north-west of Morocco along the southern shore of the Strait of Gibraltar (fig. 1). This area is located at the north-western edge of the Rif chain (fig. 2A), which consists of stacked nappes generated in an Oligo-Miocene multiphase compressive tectonic environment (Durand-Delga, 1960, 1962, 1972; Mattauer, 1963, 1964; Marçais and Suter, 1966; Andrieux, 1971, 1975 in Rampnoux et al., 1977). During the Pliocene, brittle tectonics were directly associated with the opening of the Strait of Gibraltar. Marine water then invaded the depressed area that currently separates the two sides of the Strait of Gibraltar (Durand-Delga, 1995). This NE-SW extensional phase formed a horst and graben coast (Rampnoux et al., 1977; El Fahssi, 1999). Throughout the Quaternary, the south shore of the Strait of Gibraltar experienced constant uplift (El Gharbaoui, 1977). After the last interglacial period (128 kyr), the central part of the Gibraltar Arc became associated with uplift of the Strait (Cadet et al., 1977; El Gharbaoui, 


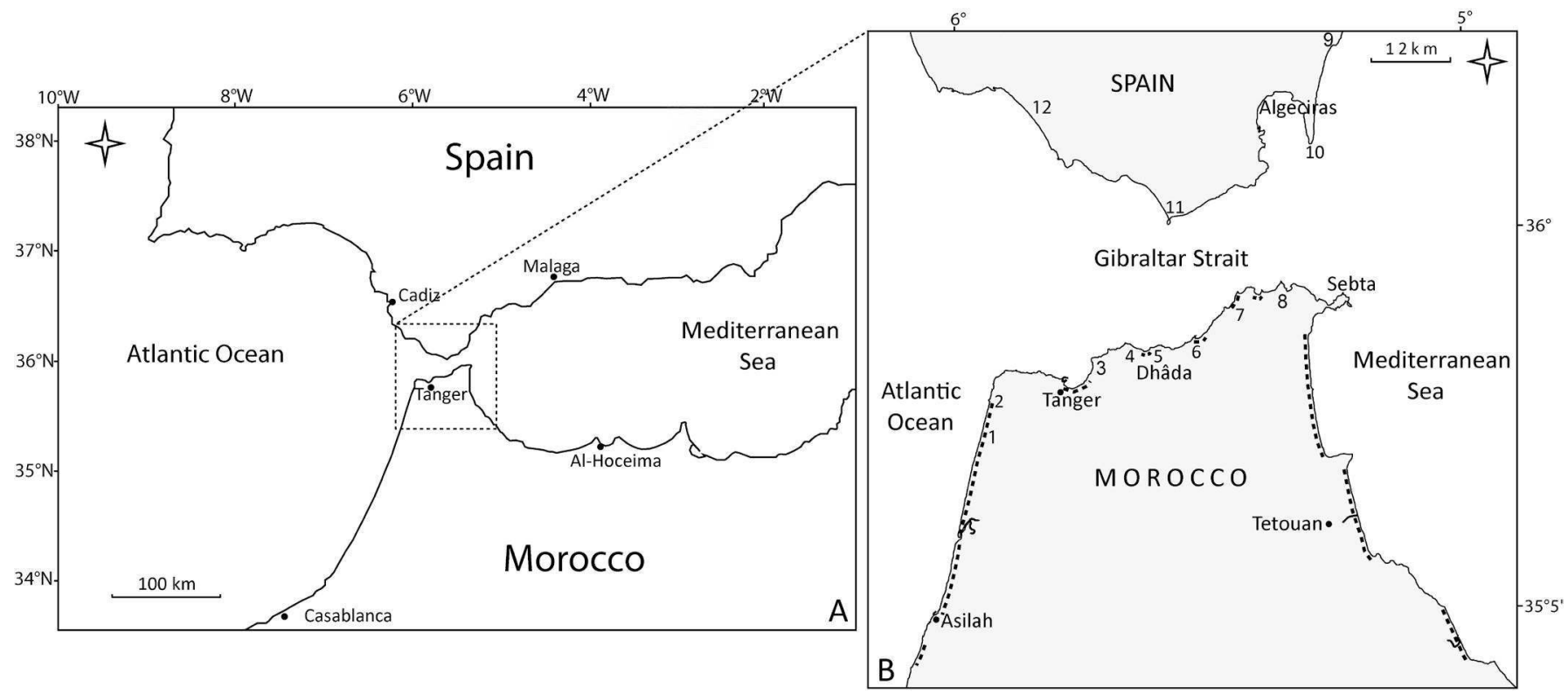

Fig. 1 - Situation of study area (A) and location of different terraces (B). 1. Airport; 2. Achakkar; 3. Malabata Cap; 4. Hejar Lasfar; 5. Dhâda; 6. Zhâra; 7. Ras-Ciress; 8. Ras-Leona; 9. Linea; 10. Gibraltar rock; 11. Tarifa; 12. Zahara. Sandy coast in dashed line.
Fig. 1 - Situation de la zone d'étude (A) et localisation des terrasses marines sur les deux rives du détroit de Gibraltar (B).

1. Aéroport ; 2. Achakkar ; 3. Cap Malabata ; 4. Hejar Lasfar ; 5. Dhâda ; 6. Zhâra ; 7. Pointe Ciress ; 8. Ras-Leona ; 9. La Linea ; 10. Rocher de Gibraltar ; 11. Tarifa 12. Zahara. Les côtes sableuses sont indiquées en pointillé.
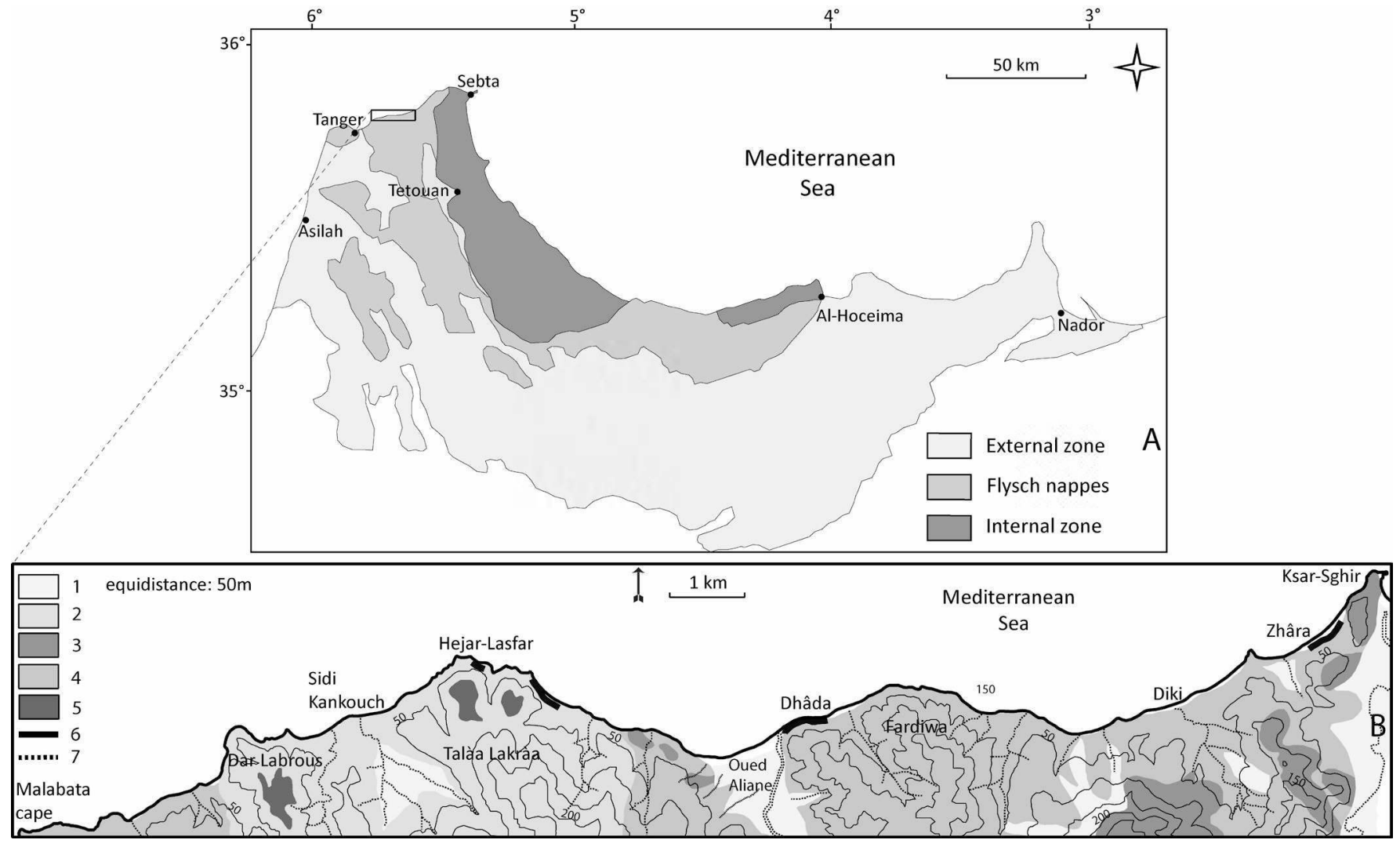

Fig. 2 - The geological context of the study area.

A. The geological units of the western part of the Rif. B. Local geology: 1. Quaternary; 2. Talà-Lakràa unit; 3. Tisirène nappe; 4 . Beni Ider nappe $(2,3$, and 4 form the Ante-quaternary bedrock); 5 . Wave-cut surfaces; 6 . The Studied marine terraces; 7. Hydrographic network.
Fig. 2 - Contexte géologique de la zone d'étude.

A. Les unités géologiques de la limite occidentale de la chaine du Rif. B. Géologie locale: 1. Quaternaire; 2. Unité de Talàa-Lakraà ; 3. Nappe de Tisirène; 4. Nappe de Beni-Ider (2, 3 et 4 forment le substratum antéquaternaire) ; 5. Surfaces d'abrasion marine; 6. Terrasses marines étudiées; 7. Réseau hydrographique. 
1977; El Fahssi, 1999; Zazo et al., 1999, 2003; Rodriguez-Vidal et al., 2004).

The geology of the Tingitane peninsula includes three structural units (fig. 2A): the internal Rif, Meso-Rif (flysch nappes) and the external Rif. The internal Rif is composed of metamorphic Paleozoic rocks and Cenozoic limestone formations. The Meso-Rif corresponds to the lower Cretaceous to Miocene flysch nappes. The external Rif is composed of Cretaceous clay and marl.

The central part of the Strait of Gibraltar coast is rugged, mainly consisting of rocky cliffs. The Atlantic and Mediterranean coasts are generally low, straight and sandy (fig. 1B).

On the Moroccan shore of the Strait of Gibraltar, the MIS 5e terraces are observed at twenty meters from the present shoreline. In contrast, outside the arc (Atlantic coast) and, to a lesser extent, along the Mediterranean coast (Alboran Sea), the fossil terraces are stable or subsiding (Cadet et al., 1977; El Gharbaoui, 1977).

Geomorphological and sedimentological field observation data from between Tangier and Ras Ciress (fig. 1B) indicate that the MIS 5 is constituted of well-consolidated marine deposits or ancient cliffs alignments. The deposit thicknesses vary from 2 to $4 \mathrm{~m}$ (El Gharbaoui 1977; El Fahssi, 1999; Aboumaria et al., 2006). The paleoshoreline is presently at between 8 and $20 \mathrm{~m}$ ASL (Cadet et al., 1977; El Gharbaoui, 1977; El Fahssi, 1999). The central block between Cape Malabata and Zhâra (fig. 1B) exhibits an upward movement of 5 to $14 \mathrm{~m}$, with the maximum preserved in the center of the south side (El Fahssi, 1999).

Along the edge of the western shore, the marine Achakkar terraces (fig. 1B) are composed by calcareous and lumachellic sandstones formed in the early Quaternary (Bourcart, 1930; Lecointre, 1952). They were deposited during several transgressions, hence the name hawksbill terraces. Lecointre (1952) and Gigout (1957) distinguished an erosive phase in the main formation at a height of $5 \mathrm{~m}$ ASL. Additionally, Brébion et al. (1986) identified a glacio-eustatic marine formation located at $6 \mathrm{~m}$ ASL which was dated to $125 \pm 10 \mathrm{kyr}$ using the U/Th method (Stearns and Thurber, 1965).

At the eastern border, the wave-cut platform of Ras Leona (fig. 1B) was dated to $114 \mathrm{kyr}$ by the U/Th method using travertine, in absence of marine deposits (El Kadiri et al., 2010). The last interglacial MIS 5 is located at 4-5 m MSL. In the same locality, Abad et al. (2013) suggested an age of $130 \mathrm{kyr}$ for the first MIS 5e highstand terrace, now located at 13 and $15.5 \mathrm{~m}$ ASL, and an age of $83 \mathrm{kyr}$ for the MIS 5a terrace, now located at 5 to $8 \mathrm{~m}$ ASL.

On the Spanish side of the Strait of Gibraltar, the MIS 5e terraces (128 kyr) range from $5 \mathrm{~m}$ to $20 \mathrm{~m}$ ASL between Zahara and the rock of Gibraltar (fig. 1B) (Zazo et al., 1999; Rodriguez et al., 2004). The greatest uplift is observed in the centre of the Strait, where MIS $5 \mathrm{e}$ is located at $20 \mathrm{~m}$ ASL in Tarifa. Terraces height decreases westwards to $14 \mathrm{~m}$ at Zahara. The MIS 5e terrace is located at $10 \mathrm{~m}$ in Algeciras and at $6.5 \mathrm{~m}$ in Linea on the Mediterranean coast (fig. 1B).

\section{Methods}

Stratigraphic and geomorphological observations were conducted before analyzing the sections observed of the studied terraces. Fossil samples were collected and dated using the U/Th method and thermal ionization mass spectrometry (TIMS). Samples used for dating were collected on the basis of the stratigraphic series. They are found in coarse carbonate sands with pebble. We chose to date Dendrophyllia ramea (Linnaeus) fossils, which are corals from the Anthozoa family. Corals with less than $3 \%$ calcite yield correct ages, provided they were not contaminated by a secondary aragonite cementation. On the contrary, Mollusc shells yield rejuvenated ages, typically due to later incorporation of marine or terrestrial uranium
(Choukri et al., 1999, 2007). Height measurements were performed using a topographic dumpy level. Granulometric and morphoscopic sand analyses were conducted to determine the genetic origins of certain facies.

\section{Study area and chronostratigraphy of marine terraces}

The study area covers $13 \mathrm{~km}$ of rocky coastline (fig. 2B) with vertical or steeply sloping cliffs. It is interspersed with limited sandy beaches, except at the mouth of the oued Aliane, where the plain is relatively wide. The geology was formed by stacking three Paleocene and Oligocene flysch nappes, including the Beni Ider nappe, Tisirène nappe and Talà-Lakràa nappe (fig. $2 \mathrm{~B}$ ). The area was thrust onto the Cretaceous clay-marl substratum of Tangier unit. The Beni Ider nappe is composed of alternating Oligocene micaceous sandstone and gray-blue clay-marl strata and Senonian flysch clay-limestone strata. The Tisirène nappe is composed of alternating yellow sandstones and mottled Barremian-Albian clays. The Talà-Lakràa unit is composed of red sandy clays and sandy Paleocene-Eocene limestone. The set of nappes exhibits a complex folded and faulted structure. The geomorphology is highly controlled by lithology, geometry and stratum thickness.

Three marine terraces were studied: the terrace of Zhâra in the east, the terrace of Dhâda in the center and the terrace of Hejar-Lasfar in the west (fig. 2B). The Dhâda terrace, which is identified for the first time, was analysed in detail. It is well developed along $1 \mathrm{~km}$ of coastline at east of Aliane river mouth (fig. 2B). Throughout the section, the beach is dominated by a cliff cut into the Beni Ider flysch (fig. 3), with dipping layers in the study section.

At Dhâda, foreshore geomorphology is characterized by a succession of lateral sandstone beds, which have been accentuated by differential erosion due to wave action (fig. 3). On the lower foreshore, argillite strata, with deep gully surfaces compared to the sandstone beds, are covered with sand, shells, pebbles and sandstone blocks from neighboring benches (fig. 3). The rear beach is sandy and includes aeolian deposits, which form dunes to the cliff bottom in relatively sheltered areas. Hard sandstone benches extend out into the water, forming a natural groyne system that protects the beach. Shoreline morphostructure is controlled by a combination of geological (lithology, geological structures and tectonics), hydrodynamic (waves and currents) and weather (wind and rain) factors. These factors control the cliff evolution and sandy beach dynamics. Clay-marl surface runoff carved drains in the benches (fig. 3). The erosive action of meteoric agents produces pebbles and rock blocks, which mainly originate from the clayey-limestone or sandstone benches fractured by tectonic activity. Stony deposits accumulate on slopes and at the bottom of the cliff (fig. 3). Depending on location, their presence, size and concentration can vary. The block shape is angular to sub-angular.

A comparative analysis between current geomorphological and sedimentological characteristics and those of Dhâda terrace suggest that the deposition environment of the two periods were very similar. In both cases, the lithology and structural features of the bedrock are paramount. Differential bedrock erosion produced irregular topography throughout the study area. Therefore, the local marine sequences are relatively variable. The sequence has a thickness of several decimeters in area in contact with clay-marl bedrock. Early transgressive deposits are better developed and marked by pebbles and sandstone blocks. In contrast, sandstone benches, exhibit differential erosion, and early transgressive deposits are restricted or absent (fig. 3A). 


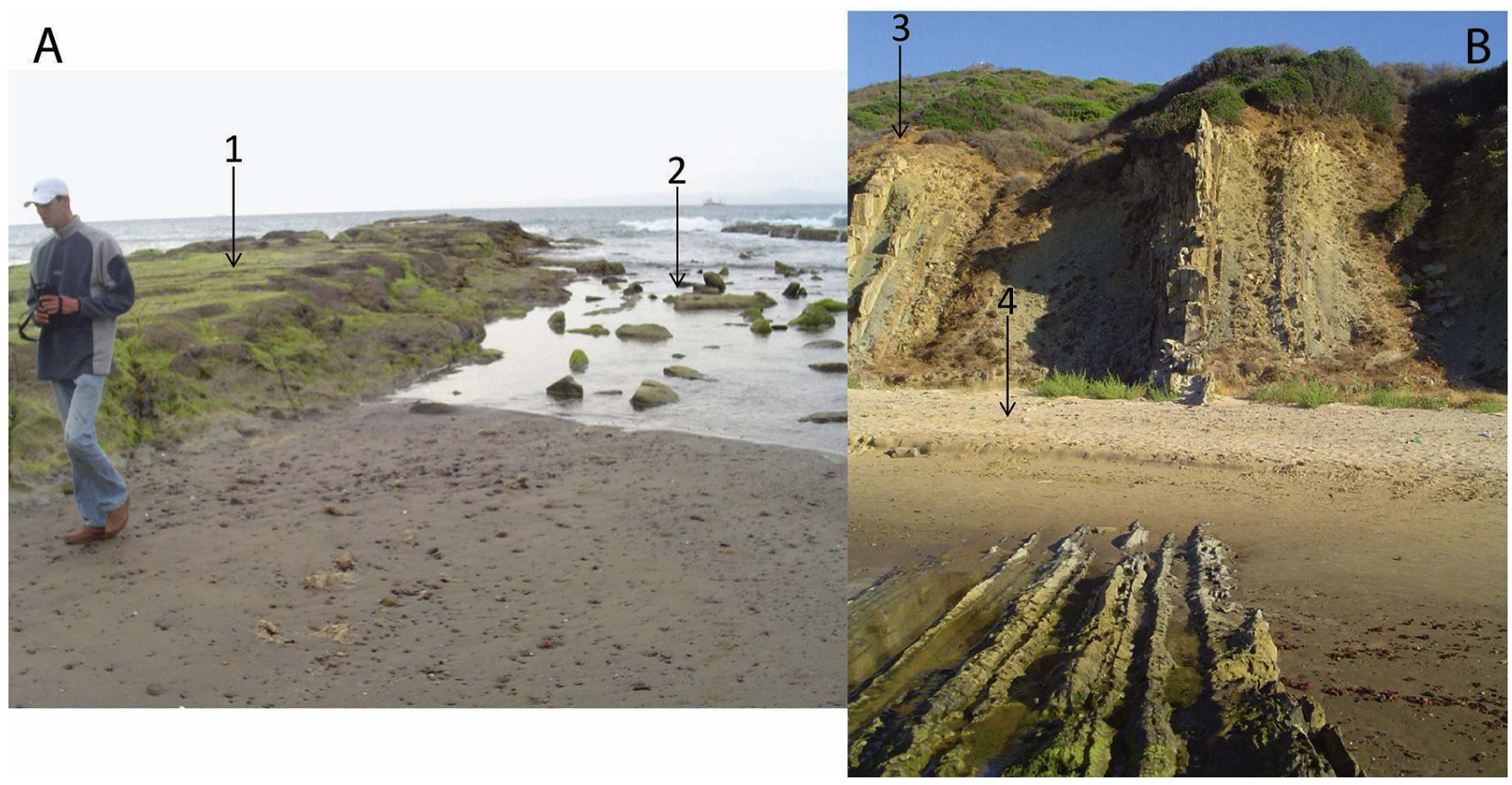

Fig. 3 - Current coastal geomorphology controlled by bedrock geology (at Dhâda).

A. It is characterized by lateral sandstone beds accentuated by differential erosion due to wave action. Argillite strata are covered with sand, pebbles and sandstone blocks. B. The cliff is cut into the Beni Ider flysch and topped by $5 \mathrm{e}$ marine terrace. 1. Current wave-cut surface; 2 . Sediment tank; 3 . Marine terrace 5 e; 4 . Current beach.

Furthermore, differential erosion of subvertical layers produces a particular situation where sea water supplies sedimentological source materials (fig. 3A). Tall calcareous sandstone benches in the intertidal zone are pummelled by waves. Detached rocks accumulated in basins cut in the clay benches. These deposits are then redistributed to the foreshore by breaking waves. The gravel size decreases in direction of the foreshore (fig. 3A).

\subsection{Dhâda marine terrace}

Marine deposits extend over $1 \mathrm{~km}$ off the coastline (fig. 4). The terrace base height is between 13 and $16 \mathrm{~m}$. Altitudinal variations are mainly due to the irregularities in the antecedent topography and coastline configuration. The total series thickness is approximately $5 \mathrm{~m}$.

The Dhâda marine terrace deposit appears in several areas. It is fairly well preserved in some sites, is presented by only vestiges sediment in others. In some places, the marine terrace is covered by a decimeter of a slope deposit composed of blackish clay. The clayey slope deposits are the result of bedrock erosion, including landslides in argillites saturated with meteoric water. This geomorphic feature visibly contributed to preserving Dhâda series from erosive agents.

\subsubsection{Stratigraphic sequence}

The stratigraphic sequence of Dhâda exhibits six distinct sedimentary units (fig. 5):

- Unit U1: This unit is located at the base of the series and unconformably overlies the Oligocene Beni Ider flysch. It is limited at the base by a wave-cut surface. The basal facies is composed of centimeter to decimeter sized pebbles. The nature of the pebbles indicates that the bedrock is the main material source. The pebbles
Fig. 3 - La géomorphologie côtière actuelle est contrôlée par la géologie du substratu m (à Dhâda).

A. Elle est caractérisée par des bancs de grès mis en relief par l'érosion différentielle, sous l'action des vagues. Les bancs d'argilite sont couverts par des sables, galets et blocs rocheux. B. La falaise est taillée dans les flyschs de Beni-Ider et surmontée par la terrasse 5e. 1. Surface d'abrasion marine actuelle; 2. Cuvette de sédimentation; 3. Terrasse marine $5^{e} ; 4$. Plage actuelle.

consist of calcareous sandstone and limestone from Beni Ider flysch. This suggests local transport mechanisms. However, some shells, particularly patellidae, and isolated algae fragments are also observed. The thickness of the unit is $0.3 \mathrm{~m}$.

- Unit U2: This unit is composed of massive calcarenite, with rare algae fragments. The thickness of the unit is $0.2 \mathrm{~m}$ (fig. 5-6).

Tab. 2 - The macrofauna association of Dhâda terrace.

It delivers a combination of species living at depths ranging from intertidal to subtidal zone. Dating was performed especially on Dendrophyllia ramea (Linnaeus) coral. The determination of the macrofauna was performed by the "Departamento de Biología" of the University of Las Palmas de Gran Canaria (Spain).

\section{Tab. 2 - Association de la macrofaune du Dhâda.}

Elles offrent une combinaison d'espèces vivant à des profondeurs allant de la zone intertidale à la zone subtidale. Les datations ont été réalisées en particulier sur le corail Dendrophyllia ramea (Linné). La détermination de la macrofaune a été réalisée par le «Departamento de Biología» de l'université de Las Palmas de Gran Canaria (Espagne).

\begin{tabular}{lll}
\hline & Family & \multicolumn{1}{c}{ Genus } \\
\hline Gastéropods & $\begin{array}{l}\text { Patella ferruginea Gmelin } \\
\text { Gibbula philberti (Recluz) } \\
\text { Charonia nodifera (Lamarck) } \\
\text { Cirsotrema (Gyroscala) commutatum } \\
\text { (Monterosato) }\end{array}$ \\
\hline Crustaceans & - Cirripedes & $\begin{array}{l}\text { Balanus perforatus Bruguiere } \\
\text { Ocypoda cursor (Linnaeus) }\end{array}$ \\
\hline Lamellibranchs & & $\begin{array}{l}\text { Chlamys varia (Linnaeus) } \\
\text { Anomia ephippium (Linnaeus) } \\
\text { Cerastoderma glaucum (Bruguiere) Venus }\end{array}$ \\
\hline Cnidarians & Anthozoans & $\begin{array}{l}\text { Dendrophyllia ramea (Linnaeus) } \\
\text { Echinoderms }\end{array}$ \\
\hline Algaes & $\begin{array}{l}\text { Paracentrotus lividus (Lamarck) } \\
\text { Mediterranean and Atlantic }\end{array}$ \\
\hline
\end{tabular}




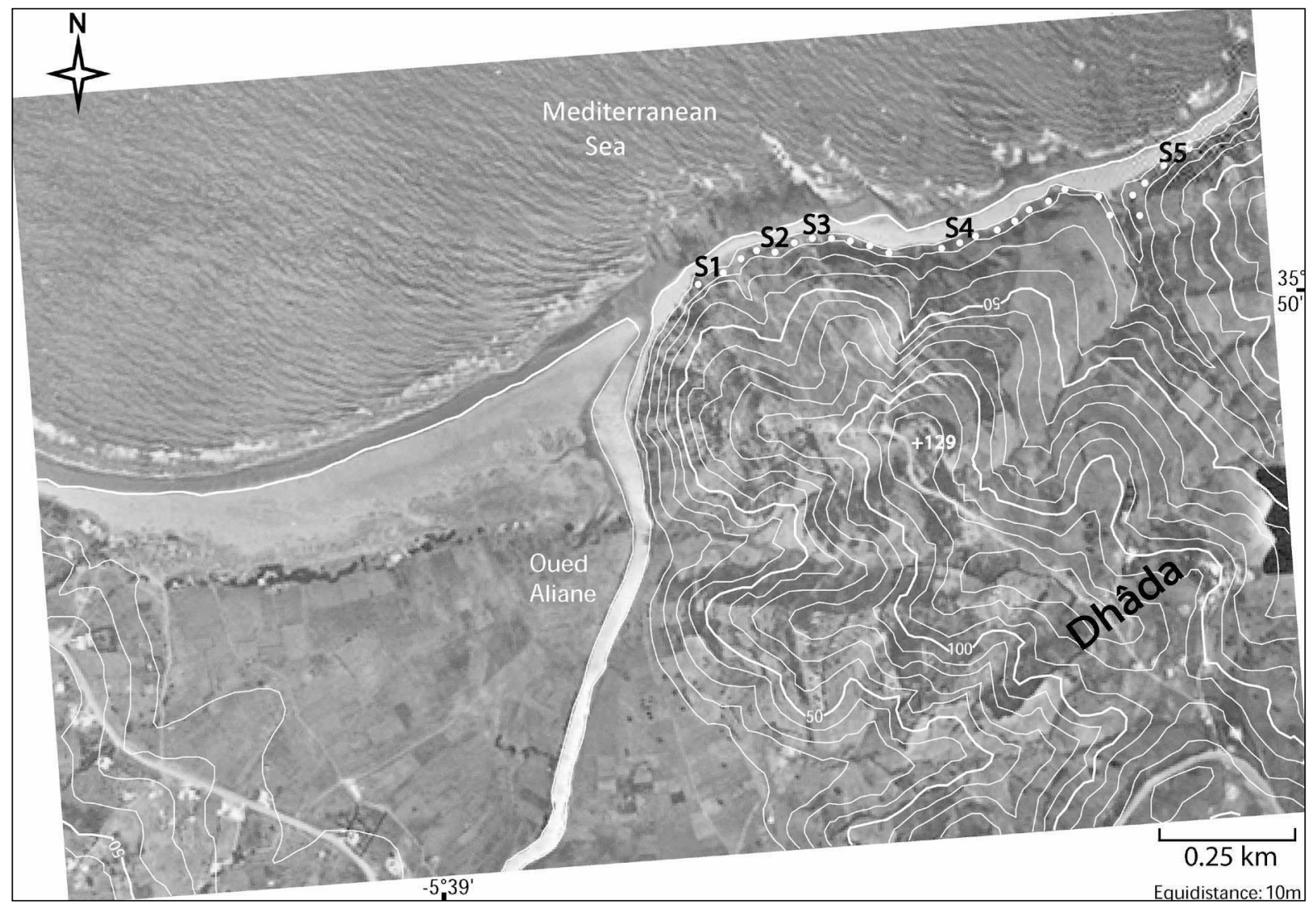

Fig. 4 - Topography of the Dhâda coast reported on aerial photograph of 1997.

The position of the marine terrace presented in bold white points. S1 to S5: situation of the analyzed samples.
Fig. 4 - Topographie de la côte de Dhâda reportée sur la photographie aérienne de 1997.

La position de la terrasse marine est présentée en points gras blanc. De S1 à S5 : position des échantillons analysés.
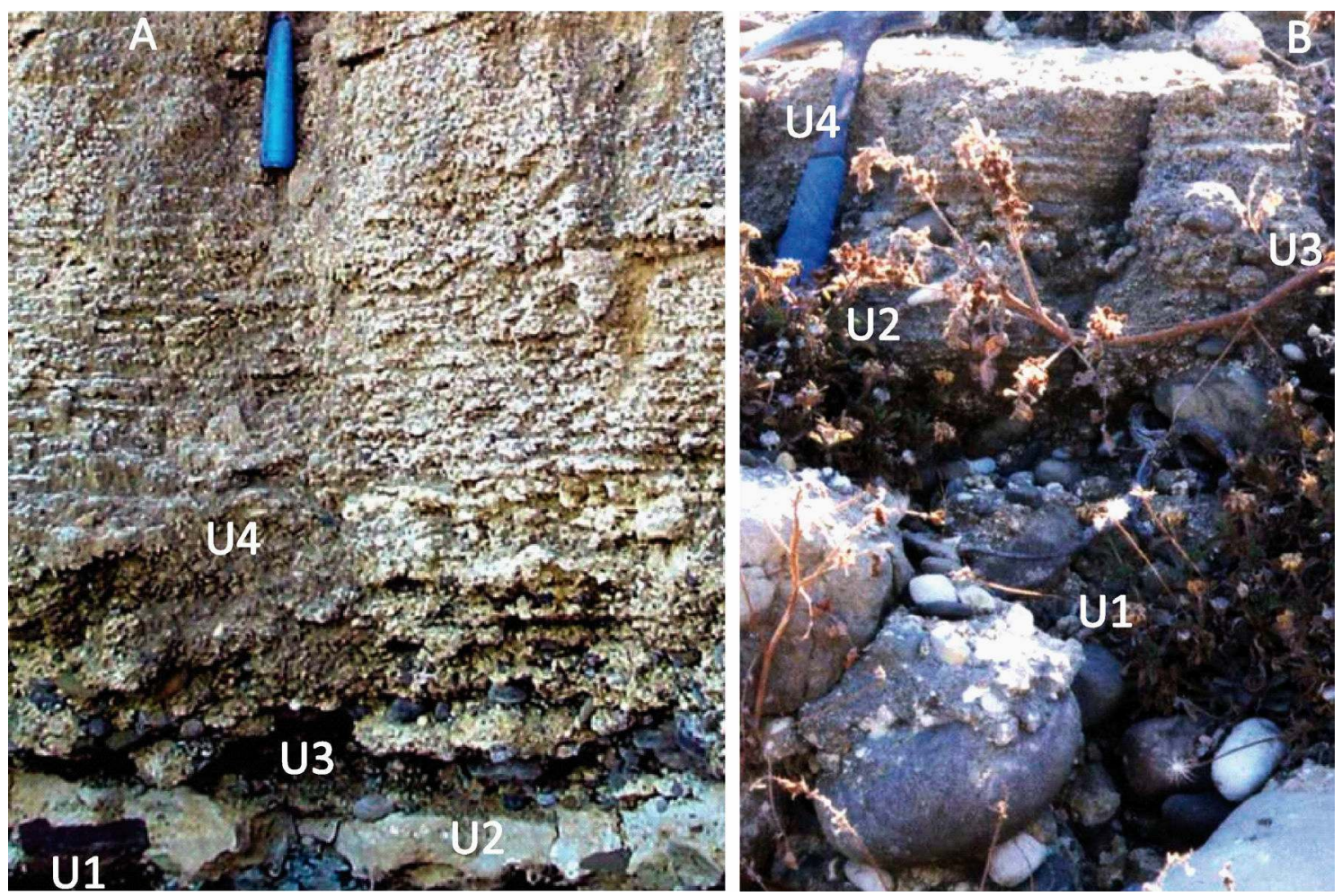

Fig. 5 - The units of the Dhâda marine terrace.

(A at S2 and B at S5, fig. 4). Transgressive units (U1 and U3) are separated by a short regressive phase (U2). U4: Intertidal sandy limestone facies with horizontal stratification.
Fig. 5 - Les unités de la terrasse marine Dhâda.

(A au site S2 et B au site S5, fig. 4). Les unités transgressives U1 et U3 sont séparées par une courte phase de régression (U2). U4: faciès intertidal formé par du sable calcaire induré en surface et présentant une stratification horizontale. 
- Unit U3: This unit is composed of a friable conglomerate with centimetric pebbles and a coarse sand matrix with abundant carbonate. It is rich in macrofauna, especially near the top of the formation (fig. 5-6). The organisms mainly consist of algae, anthozoans (corals), crustaceans, echinoderms, gastropods and lamellibranchs (tab. 2). The total thickness of the unit is $0.4 \mathrm{~m}$.

- Unit U4: This unit is composed of yellowish carbonate sand with horizontal stratification. It features alternating centimeter-thick friable sand layers and relatively indurated sands, resulting in a relative resistance to erosive agents (fig. 5-6). The grain size is coarser in the base and medium near the top. The total thickness of the unit is $1.2 \mathrm{~m}$. Macrofaunal remains, in particular marine gastropods and lamellibranch fragments, exist at the base.

- Unit U5: This unit is composed of a sub-angular decimetric pebbles embedded in a sand matrix (fig. 5,7 ).

- Unit U6: This unit features a non-laminated calcareous white sand facies. The total thickness of this unit is $3 \mathrm{~m}$ (fig. 5,7 ). The granulometry and grain morphologic analyses of the sand confirm an aeolian origin. This unit is also characterized by the presence of terrestrial fossil gastropods throughout the unit. The top part has been subjected to paedogenesis (fig. 5).

\subsubsection{U/Th dating of the Dhâda terrace}

Sampling was conducted at sites S2, S3 and S5 (fig. 4). Samples were taken from the U3 unit, where various macrofauna were identified.

The S2 and S3 sites are rich in anthozoans and algae enrobed in friable calcareous coarse sand and with pebbles. Dating was performed on Dendrophyllia ramea (Linnaeus) coral.

The third site, S5, is covered by clayey slope deposits. Shells were collected at a depth of $0.7 \mathrm{~m}$. The facies is composed by calcareous medium sand. Free pebbles exist at the base. Most shells are form gastropods, but others fossils, including rare algae and sponge fragments, are also present. The macrofauna is characterized by an abundance of Charonia nodifera (Lamarck) and Patella ferruginea (Gmelin). Datings analyses were conducted on the shells of Patella ferruginea (Gmelin) and Lithothamnion calcareum.

\subsubsection{Dating results (tab. 3)}

Four corals were dated in this study. Two samples were collected at the basis of the unit U3 (fig. 5). They exhibited minimum ages of $111.2 \pm 2.1 \mathrm{kyr}$ and $119.6 \pm 2.3 \mathrm{kyr}$. Two additional coral samples collected at S2. They exhibited minimum age of $96.6 \pm 2.3 \mathrm{kyr}$ and $106.8 \pm 3.3 \mathrm{kyr}$.

In these results, the $234 \mathrm{U} / 238 \mathrm{U}$ activity values are greater than the median marine value. This indicates that continental uranium was added to the system, and the calculated ages should be considered as minimum ages.

Because the samples are from the same unit, U3, we retain the S3 site ages values because they are less rejuvenated. The $\mathrm{S} 2$ site samples were likely more affected by meteoric water circulation.

Between two values of coral's age of S3 site, we retain $119.6 \pm 2.3 \mathrm{kyr}$ as the minimum age of $\mathrm{U} 3$ and therefore as a minimum age for the second transgressive phase. The first transgressive phase is the oldest.

The S5 Lithothamnion calcareum algae and the Patella ferruginea (Gmelin) species dating analyses produced ages of $85.2 \pm 2.8 \mathrm{kyr}$ and $53.3 \pm 2.3 \mathrm{kyr}$, respectively. These ages are significantly lower than those of S3. We believe that these ages were rejuvenated by later incorporation of uranium. Choukri et al. $(1999,2011)$ conducted U/ Th dating of 125 coral samples and 119 mollusk shells and 11 urchin spines of Egypt and Morocco. They concluded that corals and urchin spines were more reliable for dating.

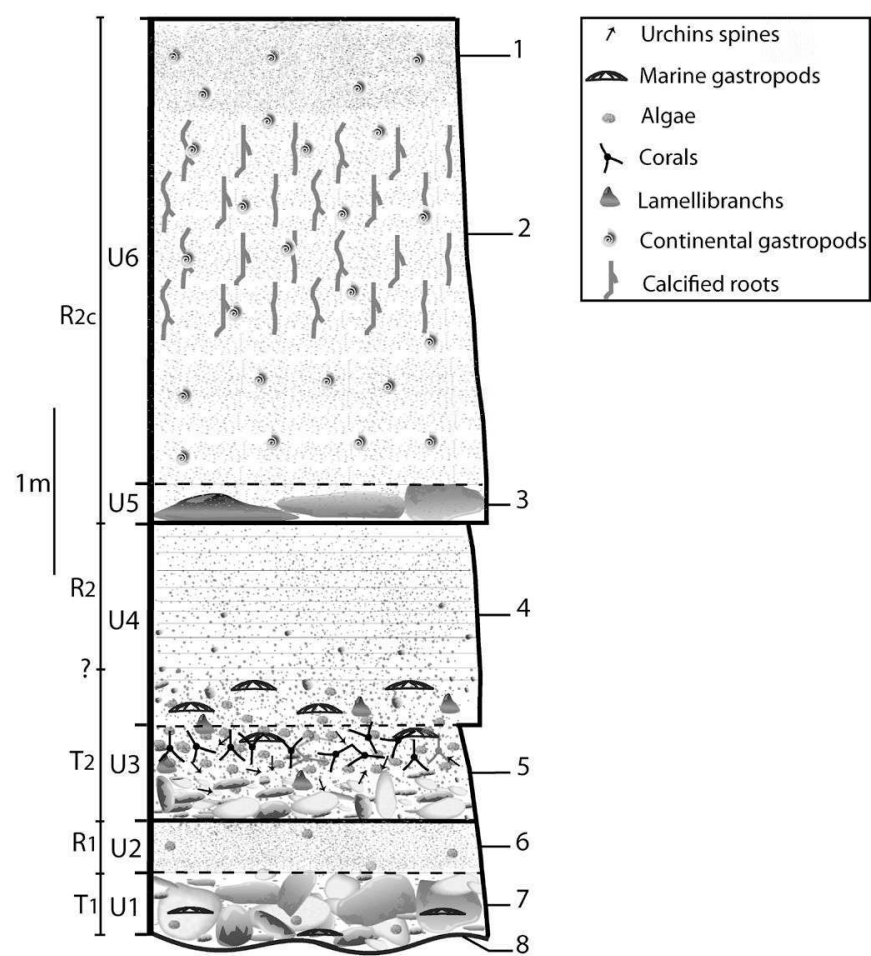

Fig. 6 - Stratigraphic section of the Dhâda marine terrace.

It consists of two transgressive deposits, U1 and U3. The U6 unit has evolved in a continental environment. T: transgression; R: regression; (c): continental; 1. Sandy soil; 2. Aeolian sand with terrestrial fossil gastropods and calcified plants root; 3. Sub-angular pebbles basement; 4. Friable carbonate sand with horizontal stratification; 5 . Transgressive pebbles with coarser sand rich in fossils; 6 . Massive calcarenite; 7 . Transgressive conglomerate with shells; 8 . Wave-cut surface.

Fig. 6 - Coupe stratigraphique de la terrasse marine de Dhâda.

Elle est formée de deux charges transgressives U1 et U3. L'unité U6 a évolué dans un contexte continental. T: transgression ; $R$ : régression ; (c) continental ; 1 . Sol sableux ; 2. Sable éolien avec des fossiles de gastéropodes terrestres et des racines calcifiées; 3. Placage de galets anguleux; 4. Sable friable à stratification horizontale; 5. Sable grossier à galets transgressifs et riche en fossiles; 6 . Calcarenite massive; 7 . Conglomérat transgressif à coquilles; 8. Surface d'abrasion marine.

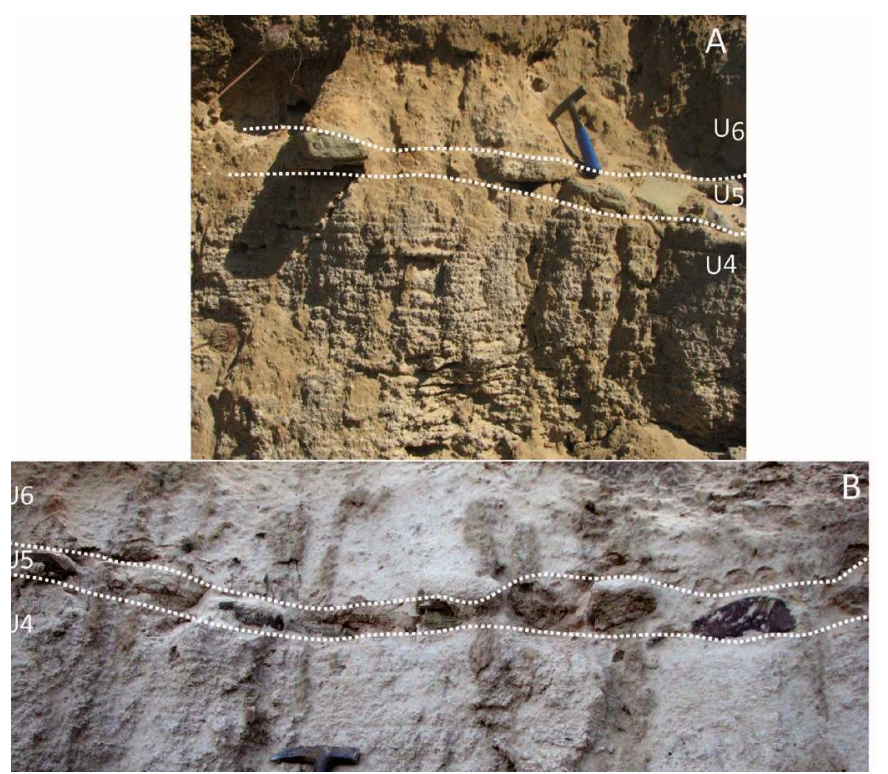

Fig. 7 - Pebble basement encounter at Dhâda marine terrace (U5).

It marks the transition of a regressive marine facies (U4) to a wind regressive facies (U6). A. General view. B. Close-up view.

Fig. 7 - Pavage de galets rencontré à Dhâda (U5).

Il marque la transition d'un faciès régressif marin (U4) vers un faciès régressif éolien (U6). A. Vue générale. B. Vue rapprochée. 
Jamal Eddine El Abdellaoui et al.

Tab. 3 - Results of U/Th Dhâda terrace dating.

The calculated ages are considered as minimum ages. Dating of five samples was performed in GEOTOP-UQAM laboratory (Canada). Latest dating performed in CERAK laboratory (Belgium).
Tab. 3 - Les résultats des datations U/Th de la terrasse marine de Dhâda.

Les âges calculés sont considérés donc comme des âges minimums. La datation des cinq premiers échantillons a été réalisée au laboratoire GEOTOP-UQAM (Canada). Le dernier échantillon a été daté au laboratoire CERAK (Belgique).

\begin{tabular}{|c|c|c|c|c|c|c|c|c|}
\hline Sample & Fauna & Unit & Height & ${ }^{238} \mathbf{U}$ (ppm) & ${ }^{230} \mathrm{Th} /{ }^{232} \mathrm{Th}$ & ${ }^{234} \mathbf{U} /{ }^{238} \mathbf{U}$ & ${ }^{230} \mathrm{Th} /{ }^{234} \mathrm{U}$ & Age (Ka) \\
\hline $\begin{array}{c}\text { S2 } \\
\text { (DC) }\end{array}$ & corail & U3 & $14 \mathrm{~m}$ & $\begin{array}{c}0.5286 \\
\pm 0.0032\end{array}$ & $\begin{array}{l}75,816 \\
\pm 1.483\end{array}$ & $\begin{array}{c}1.2252 \\
\pm 0.0100\end{array}$ & $\begin{array}{c}0.64137 \\
\pm 0.01139\end{array}$ & $\begin{array}{c}106.765 \\
+3.318 ;-3.210\end{array}$ \\
\hline S2 (FC) & corail & U3 & $14 \mathrm{~m}$ & $\begin{array}{c}1,0496 \\
\pm 0,0062\end{array}$ & $\begin{array}{l}101,372 \\
\pm 1,531\end{array}$ & $\begin{array}{c}1,3370 \\
\pm 0,0119\end{array}$ & $\begin{array}{c}0,60745 \\
\pm 0,00895\end{array}$ & $\begin{array}{c}\mathbf{9 6 , 5 8 1} \\
+2,342 ;-2,287\end{array}$ \\
\hline S3 (C1) & corail & U3 & $14 \mathrm{~m}$ & $\begin{array}{c}0,9082 \\
\pm 0,0057\end{array}$ & $\begin{array}{r}105,897 \\
\pm 1,207\end{array}$ & $\begin{array}{c}1,2958 \\
\pm 0,0109\end{array}$ & $\begin{array}{c}0,66160 \\
\pm 0,00698\end{array}$ & $\begin{array}{c}\mathbf{1 1 1 , 2 4 0} \\
+2,140 ;-2,090\end{array}$ \\
\hline S3 (C2) & corail & U3 & $14 \mathrm{~m}$ & $\begin{array}{c}1,003 \\
\pm 0,0057\end{array}$ & $\begin{array}{r}192,129 \\
\pm 2,273\end{array}$ & $\begin{array}{c}1,3132 \\
\pm 0,0093\end{array}$ & $\begin{array}{c}0,69163 \\
\pm 0,00728\end{array}$ & $\begin{array}{c}\mathbf{1 1 9 , 6 0 6} \\
+2,364 ;-2,307\end{array}$ \\
\hline S5 (B) & Algue & U3 & $15 \mathrm{~m}$ & $\begin{array}{c}1,1368 \\
\pm 0,0079\end{array}$ & $\begin{array}{l}36,699 \\
\pm 0,764\end{array}$ & $\begin{array}{c}1,3905 \\
\pm 0,0202\end{array}$ & $\begin{array}{l}0,56060 \\
\pm 0,01183\end{array}$ & $\begin{array}{c}\mathbf{8 5 , 2 2 8} \\
+2,800 ;-2,719\end{array}$ \\
\hline S5 (P) & Patelle & U3 & $15 ?$ & $\begin{array}{r}0,227 \\
\pm 0,004\end{array}$ & $\begin{array}{c}5,5 \\
\pm 0,4\end{array}$ & $\begin{array}{c}1,501 \\
\pm 0,028\end{array}$ & $\begin{array}{c}0,401 \\
\pm 0,013\end{array}$ & $\begin{array}{c}\mathbf{5 3 , 3} \\
+2,3 ;-2,2\end{array}$ \\
\hline
\end{tabular}

\subsection{Zhâra marine terrace}

Unlike Dhâda, the Zhâra marine terrace is completely endured. The thickness varies from 2 to $6 \mathrm{~m}$. Its stratigraphic sequence is composed of 6 separate units (fig. 8) and the unit thickness varies based on location.

The characteristics of each unit are presented below (fig. 8-11):

- U1 unit: This unit is composed of centimetre to decimetre pebbles embedded in a calcareous matrix forming a basal transgressive conglomerate. It rests unconformably on a wave-cut surface. The unit thickness varies between 0.3 and $0.6 \mathrm{~m}$ based on location.

- Unit U2: This unit is composed of massive calcarenite with cross-stratification. Its thickness ranges from 0.3 to $0.8 \mathrm{~m}$. The calcarenite is composed of fine to medium grains. It is separated from the first unit by a rough horizontal surface, which is often unrecognizable (fig. 9A).

- Unit U3: This unit is composed of sandy massive calcarenite with centimeter-size pebbles. This facies exhibits inverse graded bedding, gradually evolve toward a higher energy environment. Rolled pebbles are absent in some location, giving way to a coarse-grained calcarenite. In other locations, pebbles have been replaced by a cross-bedded biocalcarenite with coarse sand. This variability reflects a lateral facies variation based on water depth (under the same climatic conditions). The depositional environment was relatively high energy. The unit's thickness is 0.4 to $0.6 \mathrm{~m}$, and unit is separated from U2 by a subhorizontal surface (fig. 9A-A').

- Unit U4: This unit is composed of massive calcarenite with medium grain sizes and horizontal stratification. The thickness of the unit is greater than $1 \mathrm{~m}$, and thickness of laminations is millimetric. The unit is separated from unit U3 by a subhorizontal surface, which is not always distinguishable.

- Unit U5: This unit is composed of massive calcarenite with cross-stratification. It can be distinguished from the previous formation by the presence of bioturbation and thick laminations (fig. 10). The thickness of this layer is 0.4 to $0.6 \mathrm{~m}$.

- Unit U6: This unit is composed of calcarenite with irregular surfaces created by meteoric water erosion (fig. 11A). It is characterized by plant root calcification and by the presence of fossilized wood and vertically elongate structures (fig. 11B). It

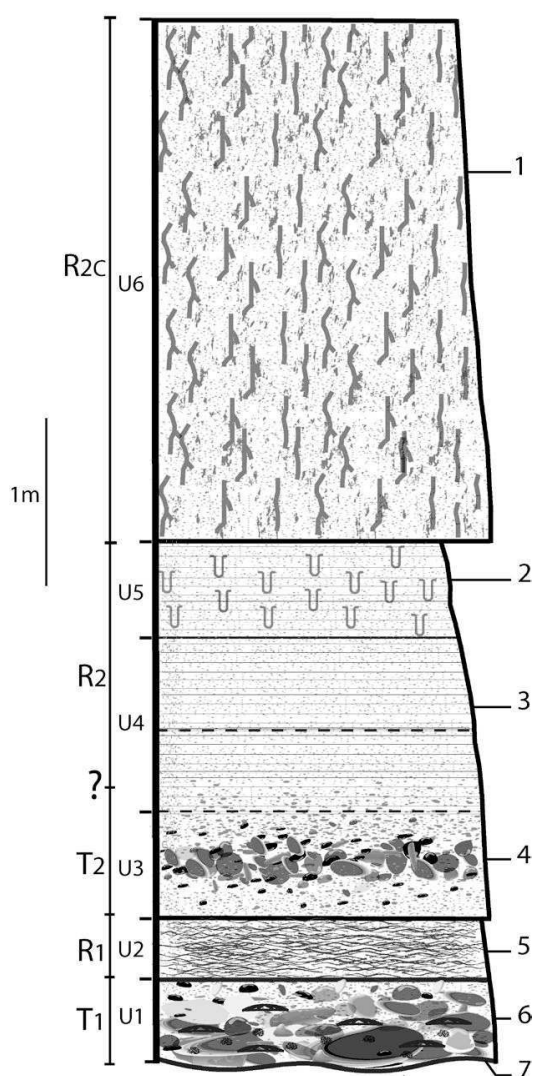

Fig. 8 - Stratigraphic section of Zhâra marine terrace.

It consists of two transgressive deposits (U1 and U3 units). The U6 unit has evolved in a continental environment. T: transgression; R: regression; 1 . Aeolian sandstone with calcified plants root; 2. Calcarenite with horizontal stratification and bioturbation 3. Calcarenite with horizontal stratification; 4. Coarser calcarenite sand with transgressive pebbles; 5 . Massive calcarenite with cross-lamination; 6 . Transgressive conglomerate with shells; 7 . Wave-cut surface.

Fig. 8 - Coupe stratigraphique de la terrasse marine de Zhâra.

Elle se compose de deux dépôts transgressifs U1 et U3. L'unité U6 a évolué dans un environnement continental. T: transgression; R: régression; 1 . Grès éolien à racines calcifiées ; 2. Calcarénite à stratification horizontale et bioturbation; 3. calcarénite à stratification horizontale; 4 . calcarénite à sable grossier et à galets transgressifs 5. Calcarenite massive avec stratification entre croisée ; 6 . Conglomérat transgressif à coquilles; 7. Surface d'abrasion marine. 


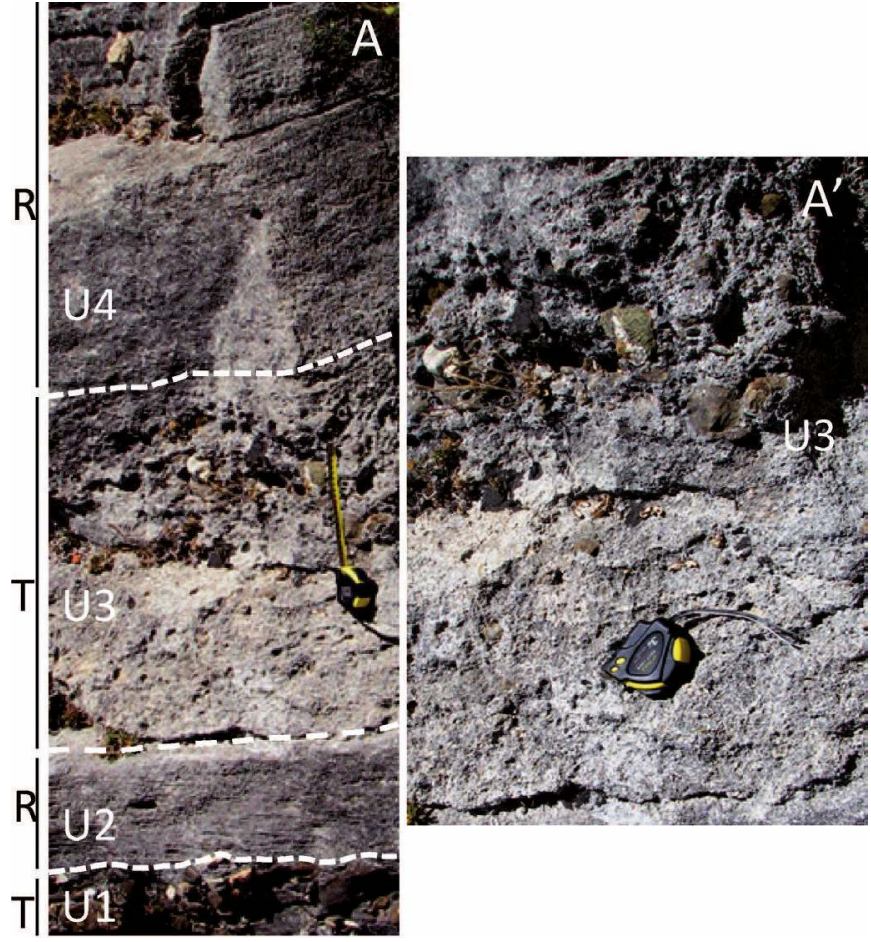

Fig. 9 - The Zhâra marine terrace.

A. General view. It presents two transgressive pulses (U1 and U3) which are separated by regressive phase (U2). A'. Close-up view. The unit «U3» exhibit inverse graded bedding. T: transgression; R: regression.

\section{Fig. 9 - La terrasse marine de Zhâra.}

A. Vue générale. Elle présente deux pulsations transgressives, U1 et U3, elles sont séparées par la phase régressive U2. A'. Vue rapprochée. La transgression U3 montre un granoclassement inverse. T: transgression; $R$ : régression.

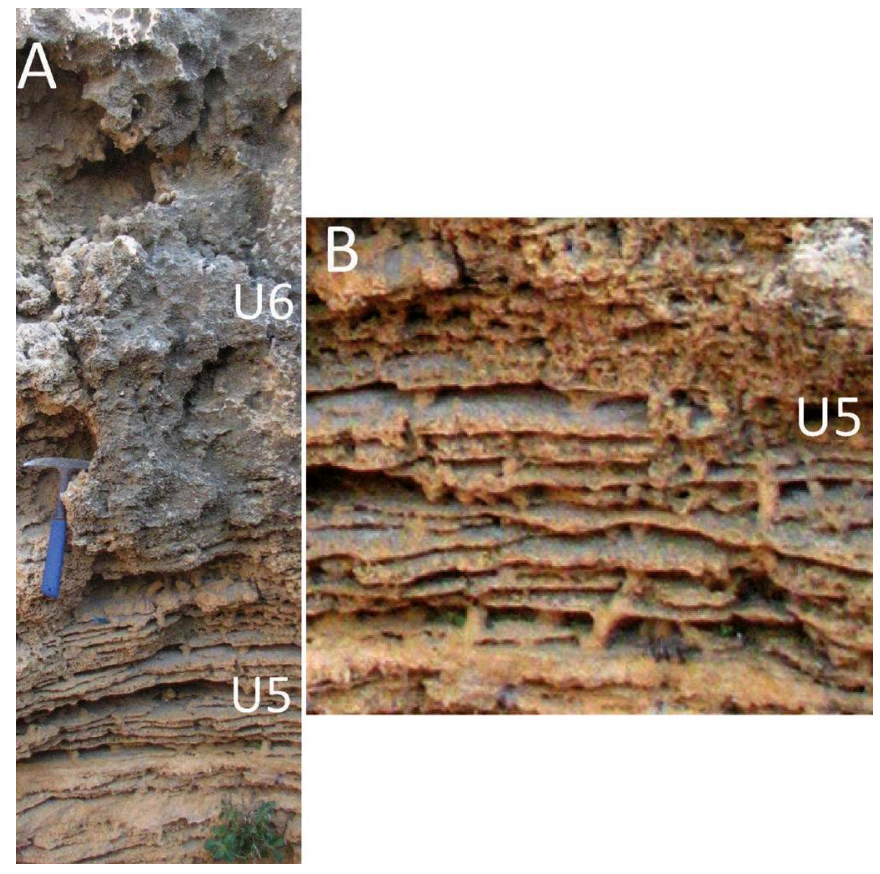

Fig. 10 - The characteristics of the unit U5 of Zhâra marine terrace.

A. General view. B. Close-up view. The unit U5 is formed by horizontal stratification calcarenite and by bioturbation produced by burrowing organisms in the intertidal zone. U6: Aeolian sandstone.

Fig. 10 - Caractéristiques de l'unité U5 de la terrasse marine de Zhâra.

A. Vue générale. B. Vue rapprochée. L'unité U5 est formée par une calcarénite à stratification horizontale et à bioturbation produite par des organismes fouisseurs en zone intertidale. U6: Grès d'origine éolien.

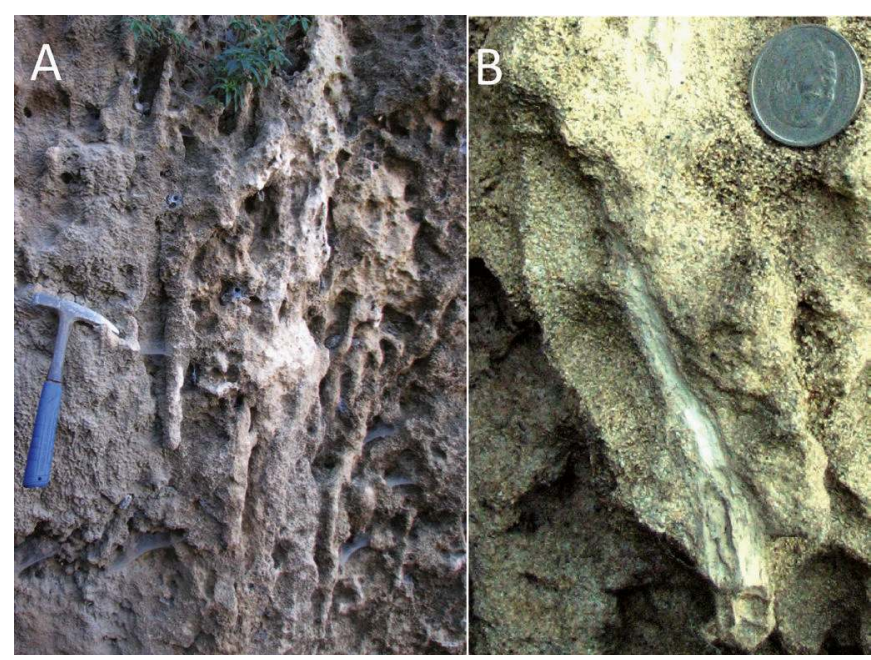

Fig. 11 - The unit U6 of Zhâra marine terrace.

It is characterized by plant root calcification, presence of fossilized wood and vertically elongate structures. A. General view. B. Close-up view.

Fig. 11 - L'unité U6 de la terrasse marine de Zhâra.

Elle est caractérisée par des concrétions racinaires, la présence de bois fossilisé et une structure verticale allongée. A. Vue générale. B. Vue rapprochée.

is separated from the previous unit by a subhorizontal surface. Thickness varies between 0.5 and $3.2 \mathrm{~m}$. This large thickness variation is mainly due to sedimentation conditions and continental erosion at the top of the terrace.

\subsection{Hejar-Lasfar Marine terrace}

The Hejar-Lasfar terrace is located at a height of 13-14 m. It has a thickness of $\pm 3 \mathrm{~m}$. In several locations, the terrace is presented as a wave-cut surface on the Talaà-Lakraà sandstone unit (fig. 2). Terrace deposits are composed by six separate units (fig. 12-13). Most are the same as the units encountered at the Zhâra terrace, with a few limited differences. The architecture of the sequence is similar to the Dhâda and Zhâra terraces. Two transgressive pulses can be identified (fig. 12A-B). The base of the series is limited by a ravinement surface cut on the bedrock at the beginning of the transgressive phase. Unit $\mathrm{U} 1$ formed during early stage of the transgression and is composed by pebbles and blocks enrobed in a calcareous matrix with medium to coarse sand.

West of Hejar-Lasfar, unit U1 is formed by a transgressive load with centimetre to decimetre pebbles. At some locations, it contains by abundant marl formed by Lithothamnium calcareum species (fig. 13). Rare Patellidae shells were collected. It is $\pm 0.8 \mathrm{~m}$ thick. Unit U2 is composed of calcarenite with medium sand. Unit U3 is a decimeter-thick layer composed of pebbles and shell fragments (fig. 12B). Unit U4 is composed of medium sand calcarenite and is $0.5 \mathrm{~m}$ thick. Unit U5 is composed of horizontally stratified calcarenite from the upper foreshore. It is $0.5 \mathrm{~m}$ thick. The series is capped by an aeolian sandstone with calcified roots. It is $\pm 1 \mathrm{~m}$ thick.

The Hejar-Lasfar terrace includes two transgressive pulses, $\mathrm{U} 1$ and $\mathrm{U} 3$, which separated by a regressive phase. The base of Hejar-Lasfar terrace is characterized by abundance of marl formed by Lithothamnium calcareum species. Unit U3 is formed by a calcarenite with coarse sand and pebbles that is rich in shell fragments. 


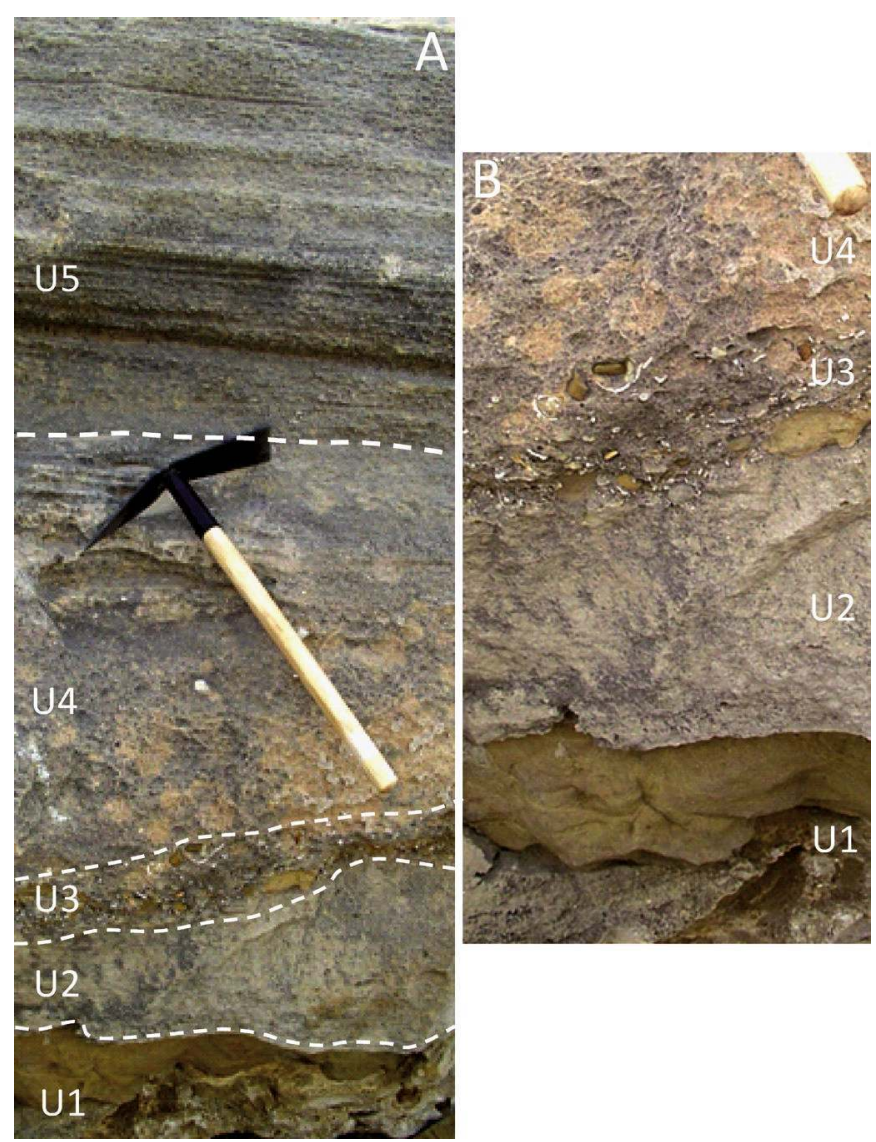

Fig. 12 - The Hejar-Asfar marine terrace.

It also presents two transgressive pulses, U1 and U3. The last one (U3) is relatively rich in shell fragments (B). The unit U5 presents an upper-foreshore horizontal stratification (A).

\section{Fig. 12 - La terrasse marine de Hejar-Asfar.}

Elle présente également deux pulsations transgressives, U1 et U3. La dernière est relativement riche en fragments de coquilles $(B)$. L'unité U5 présente une stratification horizontale d'estran supérieur (A).

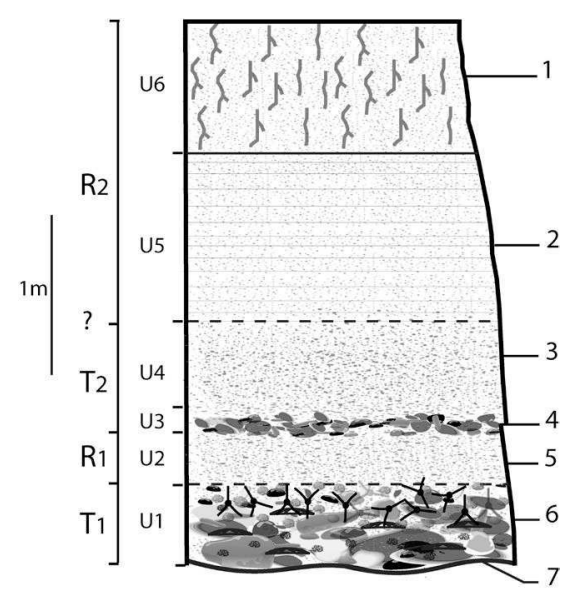

Fig. 13 - The stratigraphic section of Hejar-Lasfar marine terrace.

It is marked by two transgressive units, U1 and U3, commonly encountered along the studied area. T: transgression; R: regression; 1 . Aeolian sandstone with calcified plants root; 2 . Calcarenite with horizontal stratification; 3 . Coarser sandy calcarenite; 4. Conglomerate with shells; 5 . Massive calcarenite; 6 . Transgressive conglomerate with shells; 7. Wave-cut surface.

\section{Fig. 13 - Coupe de la terrasse marine de Hejar-Lasfar.}

On y retrouve les unités transgressives $U 1$ et $U 3$ omniprésentes dans ce secteur. T : transgression $; R$ : régression ; 1 . Grès éolien à racines calcifiées; 2 . Calcarénite à stratification horizontale ; 3 . calcarénite à sable grossier ; 4. Conglomérat à fossiles 5. Calcarenite massive; 6. Conglomérat transgressif à coquilles; 7. Surface d'abrasion marine.

\section{Results, discussion and correlations}

\subsection{Stratigraphic analysis}

The different stratigraphic sequences of the last interglacial period unconformably overlay the geological substratum. The unconformity is represented by a surface that was cut by waves during transgression. The cutting of the wave is dependent on the wave energy, relative rate of sea level rise, sediment supply and slope (Cattaneo and Steel, 2003; Catuneanu et al., 2009; Zecchin et al., 2009). The wave-cut surface of the Dhâda terrace was principally controlled by the underlaying geology. The folded structure and bedrock lithology controlled wave action (fig. 14). As a result, an undulating surface with troughs formed in the soft clayey marl, whereas ridges formed from the resistant calcareous sandstone (fig. 14).

Unit U1 is associated with marine erosion surface. It is thin basal conglomerate, with a limestone matrix and scattered shells, characterizing a transgressive sediment load (Kidwell, 1991; Cattaneo and Steel, 2003; Catuneanu, 2002; Catuneanu et al., 2009; Zecchin et al., 2009). It is common to all marine terraces in the study area, and it presents the first transgressive pulse, the age of which is likely between 128 and $125 \mathrm{kyr}$ (fig. 15). As a chronological reference, we note that Achakkar MIS 5e terrace was dated tol $25 \mathrm{kyr}$ (Stearns and Thurber, 1965), and the Spanish MIS 5e terrace was dated $\pm 128 \mathrm{kyr}$ (Zazo et al., 1999). Unit U1 has the characteristics of a low to medium shoreface. It formed under high energy
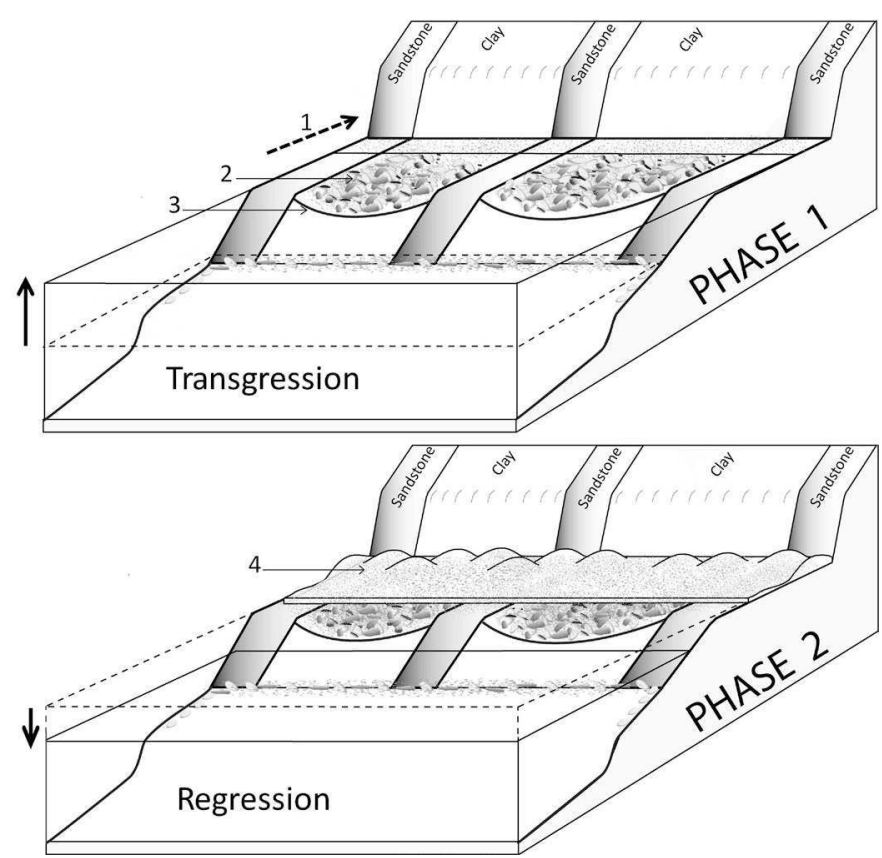

Fig. 14 - Geomorphological model of depositional evolution of Dhâda marine terrace.

Phase 1: Marine transgression accompanied by cliff retreat and by formation of irregular wave-cut surface. It is covered by a transgressive deposit. The differential erosion produces irregular bedrock topography. Phase 2: the regressive period is marked by terrestrial deposits. 1 . Cliff retreat; 2 . Transgressive pebbles; 3 . Wave-cut surface; 4. Aeolian sand.

Fig. 14 - Modèle géomorphologique expliquant l'évolution de dépôt de la terrasse de Dhâda.

Phase 1: Transgression marine avec formation d'une surface d'abrasion irrégulière couverte par un dépôt transgressif. Elle est accompagnée par le recul de la falaise. L'érosion différentielle du substratum rocheux produit une topographie irrégulière. Phase 2: La période régressive est marquée par des dépôts terrestres. 1. Retrait de la falaise ; 2. Galets transgressifs ; 3. Surface d'abrasion marine; 4. Sable éolien. 
conditions, as indicate by the presence of marine abrasion surface and decimetre to centimeter-sized pebbles. The small unit thickness is likely due to limited sediment supply.

Unit U2 is composed by a massive medium-grained calcarenite. The thickness varies from 0.15 to $0.5 \mathrm{~m}$. In some places, the calcarenite is dotted with centimeter-sized pebbles (e.g. Zhâra). Based on our observations, the sedimentation process of the U1 facies and actual upper tidal deposits facies are similar. It is a regressive phase because it occurs from low to high foreshore. The limited thickness of the deposits suggests a short forced regressive phase. The transgressive $\mathrm{U} 1$ unit and the regressive $\mathrm{U} 2$ unit are separated by a maximum flooding surface. This corresponds to the end of the transgressive phase and is marked by a change of coastline trajectory (Catuneanu, 2002; Cattaneo and Steel, 2003; Zecchin, 2007; Catuneanu et al., 2009).

In Dhâda, unit U2 is overlain by unit U3, which is composed of pebbles fossil-rich calcareous sands (fig. 15). At Zhâra, U3 is composed by a conglomerate (puddingstone) with a carbonated matrix. At Hejar-Lasfar, U3 consists of pebbles and marine shells fragments. Thus, unit U3 exhibits transgressive period caracteristics within all threestratigraphicsections (fig. 15). However, transgressive context is supported by macrofauna concentrations (Kidwell, 1991; Cattaneo and Steel 2003; Zecchin, 2007; Zecchin et al., 2009; Andreucci et al., 2009) which were relatively variable, especially at Dhâda. This reflects the redistribution of shells by wave currents (Kidwell, 1991; Zecchin, 2007). The combination of macrofauna collected (tab. 2) from the U3 unit included a mixture of species from varying depths, ranging from intertidal to subtidal. For example Lithothamnium calcareum is a red algae species that grows in intertidal to subtidal zones and form marl beds at depths of 10 to $30 \mathrm{~m}$. This species was commonly redistributed by the currents that accompanied the second transgressive phase. The facies displays characteristics of lower intertidal deposits, which are formed by relatively rough water at low to medium depth. Thus, we shift from an upper foreshore (U2) to a lower foreshore environment. The erosion surface related to a second transgressive pulse exhibits few irregularities because it was controlled by sediment produced by the first Transgression-Regression cycle that filled troughs carved by the first gullying phase. Moreover, the pebbles are generally more rounded and smaller compared to those deposited by the first transgressive pulse. Although the first transgression directly eroded the bedrock, causing cliff retreat and generating angular blocks of

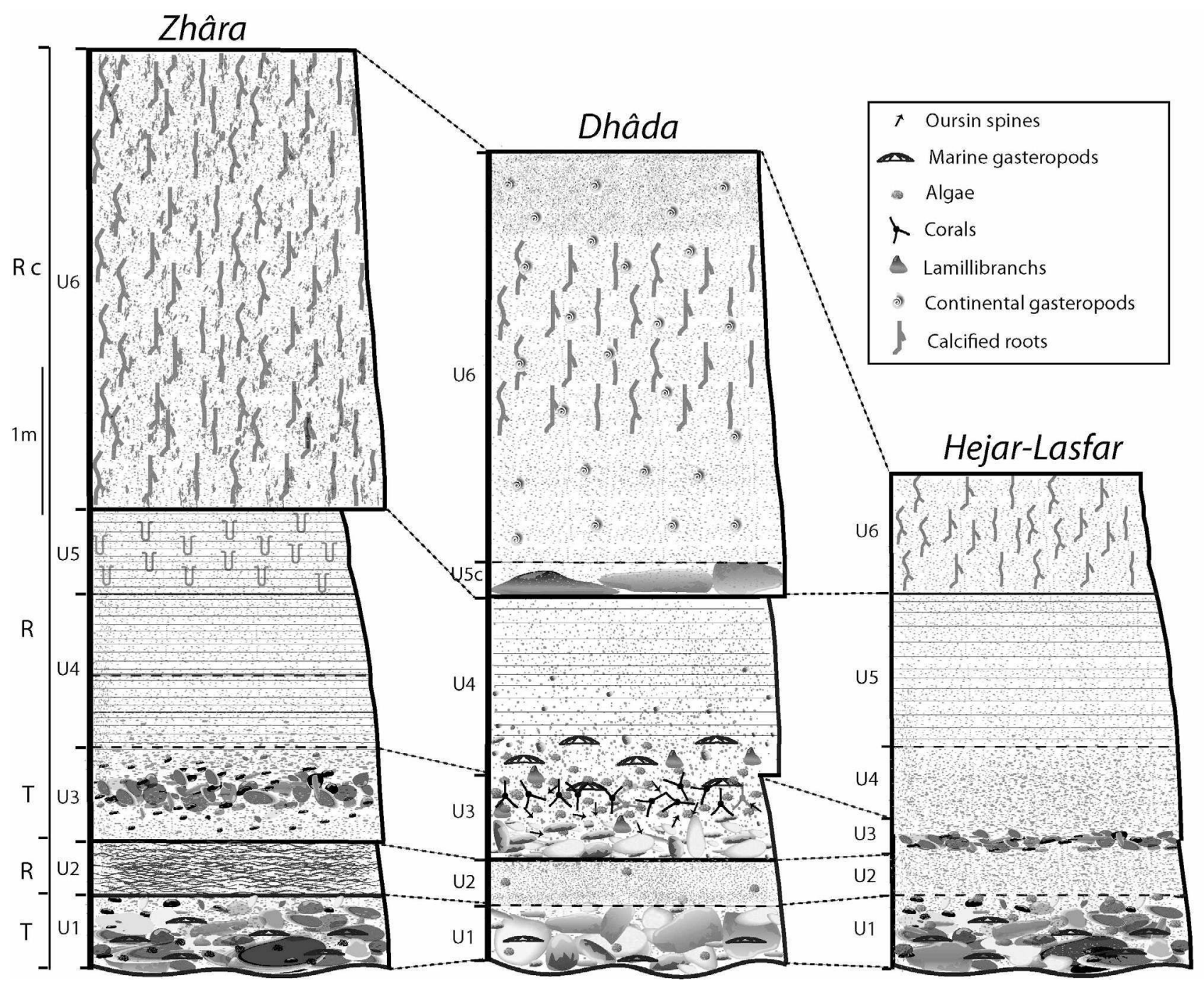

Fig. 15 - Correlation between the three stratigraphic sections.

We denote two transgressive phases common to all sections (U1 and U3). They are followed by regressive phases (U2 and U4). The top part is formed by a generalized aeolian facies.
Fig. 15 - Corrélation entre les trois coupes étudiées.

On note deux phases transgressives communes à toutes les sections (U1 et U3). Elles sont suivies par des phases régressives (U2 et U4). La partie supérieure correspond à un faciès typiquement éolien. 
native rock, the second pulse flooded a gentler geomorphology by reworking the relatively mature materials of lower foreshore. It is likely that the second pulse did not reach the foot of ancient cliffs.

The second transgressive phase gradually give way to the second and final regressive phase, which likely lasted longer. This phase constitutes $80 \%$ of total sequence thickness (U4 to U6) (fig. 15). The asymmetry between transgressive and final regressive deposit thicknesses is similar to that of a regressive «R» cycle, which occurs in clastic depositional systems and was proposed by Zecchin (2007) and Zecchin et al. (2009). The «R» cycle is common to marine Pleistocene successions, which were controlled by high amplitude glacio-eustatic variations. A rapid increase in the base level promoted the accumulation of relatively thin transgressive layers (Zecchin, 2007; Zecchin et al., 2009).

The second regressive phase is divided into two parts. The first is the marine portion (U4 at Dhâda, and U4 and U5 at Zhâra and Hejar-Lasfar) (fig. 15), and the second is the continental portion (U5 and U6 at Dhâda, U6 at Zhâra and Hejar-Lasfar). The latter marks the final withdrawal of marine waters.

At Dhâda, the regressive marine portion consists of calcareous sand with horizontal stratification. At Zhâra and Hejar-Lasfar, the regressive phase is consists of massive bioturbed calcarenite, with horizontal to cross-bedded structures (fig. 10). This facies exhibits characteristics of medium to upper foreshore deposits.

At Dhâda (unit U5), the beginning of the continental phase is marked by centimetre to decimetre pebbles (fig. 7). These subangular pebbles suggest short transport distances in an aerial context. Marine action was not significant. The pebbles were produced by meteoritic erosion of the backshore cliffs. Blocks were removed from the bedrock, tumbled by gravity and settled at the cliff foot. Winds removed light grains are and arranged pebbles in subhorizontal layers, resulting in what is known as «desert pavement» (Ozer, 1989). These processes are indicative of cold and dry climatic episodes (Ozer, 1989).

The desert pavement is overlain by $3 \mathrm{~m}$ of medium to fine-grained of calcareous sand (U6). This sand is characterized by abundant terrestrial gastropods throughout the unit. Sedimentologic and morphoscopic analysis suggest that this sand is well sorted throughout the unit. Grain morphoscopy confirms that more than $78 \%$ of grains are speckled and shiny. This shiny sand grains (mostly blunt to ovoid) were polished by wave and wind actions during transport within coastal systems. The Round matt grains (20\%) experienced longer transport processes and likely originated from the oldest aeolian formations. These results prove that sands are aeolian and were deposited in a windy and very likely cold climate.

At Zhâra, the U6 unit is well endured. It differs from the other units due to the presence of alveoli, generated by meteoritic erosion and vertical structures caused by plants root calcification (fig. 11B). These structures have been attributed to marine bioturbation by some authors (Aboumaria et al., 2006), but the fossilized wood collected within structures confirms their aeolian origin.

\subsection{Tectonic uplift of the southern shore of the Strait of Gibraltar}

In the remainder of our discussion, we assume the following assumptions.

First, the age of the second pulse recorded on terraces of the center zone of the Strait of Gibraltar is at least $119.6 \pm 2.3 \mathrm{kyr}$. The first transgressive pulse likely dates to between 128 and $125 \mathrm{kyr}$, whereas the second dates to between 121 and $118 \mathrm{kyr}$.

Second, the maximum sea level was 5-6 m ASL during MIS 5e. This represents an average of the values from various local studies (4 to $5 \mathrm{~m} \mathrm{El} \mathrm{Kadiri} \mathrm{et} \mathrm{al.,} \mathrm{2010);} 5$ to $6 \mathrm{~m}$ for Stearns and Thurber (1965) and Brébion et al. (1986). The maximum sea level approaches $6 \mathrm{~m}$ ASL along the northern shore of the strait (Zazo et al., 1999), which remains within the average range of 3 to $6 \mathrm{~m}$ recorded in several regions around the world. Recent studies suggest that the tectonic uplift in the Strait of Gibraltar was generated by active NW-SE convergence between the European and African plates. This explains most of the constraints observed in the Gibraltar Arc (El Kadiri et al., 2010; Pedrera et al., 2011). Based on the results of previous studies, the significant tectonic uplift at the eastern portion of the southern shore of the Strait of Gibraltar ceased after MIS 5e. In fact, the eastern portion of the Strait of Gibraltar is mainly controlled by eustasy (El Kadiri et al., 2010). Thus, the subduction responsible for the Gibraltar Arc development deceased (Pedrera et al., 2011). An analysis of vertical movements on the Spanish side of the Strait of Gibraltar suggests that differential uplift occurred over the last $128 \mathrm{kyr}$. It is connected to Sinistral (NE-SW) and Dextral (NW-SE) strike-slip fault systems (Zazo et al., 1999; Silva et al., 2006).

Because the most reliable chronological reference available is the age of the second transgressive pulse (unit U3), i.e. $119.6 \pm 2.3 \mathrm{kyr}$, and because the final withdrawal of sea water occurred between 118 to $116 \mathrm{kyr}$, the minimum age for early uplift of central zone is approximately $117 \mathrm{kyr}$ on average. Indeed, in absence of the evidence of tectonic activity during the last regressive phase or other chronological data, the start of the uplift could be considered $117 \mathrm{kyr}$ old. However, if we assume that the maximum sea level during MIS 5e reached $6 \mathrm{~m}$ ASL, the Dhâda terrace, located at $13-16 \mathrm{~m}$, must have raised from 7 to $10 \mathrm{~m}$. The rate of the maximum uplift over $117 \mathrm{kyr}$ was therefore between $0.06 \mathrm{~mm} / \mathrm{yr}$ and $0.085 \mathrm{~mm} / \mathrm{yr}$. Taking into account the admitted stability of the East and West zones ((Stearns and Thurber, 1965; El Kadiri et al., 2010), these results agree with the maximum uplifting of the central part of the Strait of Gibraltar, which decrease toward the East and West (Zazo et al., 1999, on the northern side; El Fahssi, 1999, on the southern side). However, our results disagree with the results of Abad et al. (2013) who established an uplifting rate of $\sim 0.1 \mathrm{~mm} / \mathrm{yr}$ over the last $130 \mathrm{kyr}$ at Ras-Leona (fig. 1). This rate is higher than that of the central zone. Their results were based on U/Th dating, which was performed on calcareous algae, resulting in an age of $83 \mathrm{kyr}$ (MIS 5a). Dating performed on unconsolidated calcareous algae, at Dhâda terrace yielded significantly younger ages than conducted on the corals of the same terrace (tab. 2). We believe that calcareous algae provides unreliable U/Th dating results, suggesting that the age of $83 \mathrm{kyr}$ given by Abad et al. (2013) was underestimated. We therefore believe that the thesis of an uprising of $0.1 \mathrm{~mm} / \mathrm{yr}$ of the eastern coast is implausible.

On the northern shore of the Strait of Gibraltar, the differential uplift of an MIS 5e terrace (128 kyr) yields a mean maximum rates of $0.10 \mathrm{~mm} / \mathrm{yr}$ (Zazo et al., 1999).

\section{Conclusion}

The stratigraphic analyses and correlations between Dhâda, Zhâra and Hejar-Lasfar marine terraces identified two eustatic transgressive pulses that occurred during MIS 5e, which is consistent with the results recorded on the Atlantic coast of Tangier (El Abdellaoui, 2014). The second pulse occurred at $119.6 \pm 2.3 \mathrm{kyr}$. The first forced regression was shorter than occurred at the end of sedimentary cycle. After the definitive withdrawal of marine water, the terrace evolved in backshore environment with windy climatic conditions. Transgressive-regressive cycle is strongly associated with the bedrock geology (lithology, structure), which controlled 
stratigraphic sequence thickness, sediment supply, wave energy and erosion surface physiography. Interaction between geology, hydrodynamics and meteorological conditions during MIS 5e was very similar to current geomorphology and sedimentary environments. Finally, stratigraphic and tectonic analyses give local uplifting at an average rate of $0.085 \mathrm{~mm} / \mathrm{yr}$, beginning at $117 \mathrm{kyr}$. The Uplift most likely occurred after the deposition of the MIS 5e series.

\section{Acknowledgements}

The authors thank Joaquín Meco (Departamento de Biología ULPGC, 35017 - Las Palmas de Gran Canaria - Canary Islands Spain) for his determination of macrofauna.

\section{References}

Abad M., Rodríguez-Vidal J., Aboumaria K., Zaghloul M.N., Cáceres L.M., Ruiz F., Martínez-Aguirre A., Izquierdo T., Chamorro S. (2013) - Evidence of MIS 5 sea-level highstands in Gebel Mousa coast (Strait of Gibraltar, North of Africa). Geomorphology, 182, 133-146.

DOI : 10.1016/j.geomorph.2012.11.004

Aboumaria Kh., Gigliuti L.G, Puglisi D., Zaghloul M.N., Abrkan M., Di Staso A. (2006) - Quaternary marine terraces on the southern side of the Gibraltar strait and on the northern Atlantic Coast of Morocco, lithstratigraphy, provenance and drainage patterns. Italian Journal of Geosciences, 125, 93-104.

Alouane M. (1997) - Le Quaternaire marin du Cap Achakar (Tanger, Maroc) : néotectonique et lithostratigraphie. Journal of African Earth Sciences, 25 (3), 391-405.

DOI : $10.1016 /$ S0899-5362(97)00112-7

Andreucci S., Pascucci V., Murray A.S., Clemmensen L.B. (2009) - Late Pleistocene coastal evolution of San Giovanni di Sinis, west Sardinia (Western Mediterranean). Sedimentary Geology, 216 (3-4), 104-116.

DOI : 10.1016/j.sedgeo.2009.03.001

Blanchon P. (2011) - Back-Stepping. Encyclopedia of Modern Coral Reefs: structure, form and process. Encyclopedia of Earth Sciences Series, David Hopley (Ed.), Springer Netherlands, 77-84.

Blanchon P., Eisenhauer A., Fietzke J., Liebetrau V. (2009) Rapid sea-level rise and reef back-stepping at the close of the last interglacial highstand. Nature, 458, 881-884.

DOI : $10.1038 /$ nature 07933

Bourcart J. (1930) - Sur la stratigraphie de la zone internationale de Tanger. Comptes Rendus de l'Académie des Sciences, série II, 191, 621-623.

Brébion P., Raynal J.P., Texier J.P., Alouan M. (1986) - Nouvelles données sur le Quaternaire atlantique à Casablanca et Achakar. Comptes Rendus de l'Académie des Sciences, Série II, 302 (14), 901-904.

Bruggeman, J.H., Buffler R.T., Guillaume M.M.M., Walter R.C., Von Cosel R., Ghebretensae B.N., Berhe S.M. (2004) Stratigraphy, palaeoenvironments and model for the deposition of the Abdur Reef Limestone: context for an important archaeological site from the last interglacial on the Red Sea coast of Eritrea. Palaeogeography, Palaeoclimatology, Palaeoecology, 203, 179-206.

DOI : $10.1016 / \mathrm{s} 0031-0182(03) 00659-\mathrm{x}$

Cadet J.P, Fourniguet J., Gigout M., Guillemin M., Pierre G. (1977) - La néotectonique des littoraux. Bulletin de la Société Géologique de France, 19 (3), 600-605.

DOI : 10.2113 /gssgfbull.s7-xix.3.600
Carr A.S., Bateman M.D., Roberts D.L., Murray-Wallace C.V., Jacobs Z., Holmes P.J. (2010) - The last interglacial sea-level high stand on the southern Cape coastline of South Africa. Quaternary Research, 73, 351-363.

DOI : 10.1016/j.yqres.2009.08.006

Cattaneo A., Steel R.J. (2003) - Transgressive deposits: a review of their variability. Earth-Science Reviews, 62, 187-228. DOI : 10.1016/s0012-8252(02)00134-4

Catuneanu O. (2002) - Sequence stratigraphy of clastic systems: concepts, merits, and pitfalls. Journal of African Earth Sciences, 35, 1-43.

DOI : 10.1016/s0899-5362(02)00004-0

Catuneanu O., Abreu V., Bhattacharya J.P., Blum M.D., Dalrymple R.W., Eriksson P.G., Fielding C.R., Fisher W.L., Galloway W.E., Gibling M.R., Giles K.A., Holbrook J.M., Jordan R., Kendall C.G.St.C., Macurda B., Martinsen O.J., Miall A.D., Neal J.E., Nummedal D., $\quad$ Pomar L., Posamentier H.W., $\quad$ Pratt B.R., Sarg J.F., Shanley K.W., Steel R.J., Strasser A., Tucker M.E., Winker C. (2009) - Towards the standardization of sequence stratigraphy. Earth-Science Reviews, 92, 1-33.

DOI : 10.1016/j.earscirev.2008.10.003

Choukri A., Reyss J.L., Jahiouh E.K., Semghouli S., Plaziat J.C. (1999) - Discussion de la fiabilité de datation de quelques matériaux par la méthode $230 \mathrm{Th} / 234 \mathrm{U}$. Application à l'étude de la variation du niveau marin dans le passé. Rencontre Franco-Marocaine de Physique Nucléaire. El Jadida, Maroc, 81-85.

Choukri A., Hakam O.K., Reyss J.L., Plaziat J.C. (2007) Radiochemical data obtained by a-spectrometry on unrecrystallized fossil coral samples from the Egyptian shoreline of the north western Red Sea. Radiation Measurements, 42, 271-280.

DOI : 10.1016/j.radmeas.2006.12.005

Choukri A., Hakam O.K., Reyss J.L. (2011) - Difficultés de datation des niveaux marins pléistocènes à l'aide de coquilles de mollusques fossiles : cas du niveau Ouljien sur la côte du Haut Atlas au Maroc. Carnets de Géologie / Notebooks on Geology, Brest. Article 2011/02 (CG2011_A02), 21-30.

Cutler K.B., Edwards R.L., Taylor F.W., Cheng H., Adkins J., Gallup C.D., Cutler P.M., Burr G.S., Bloom A.L. (2003) Rapid sea-level fall and deep-ocean temperature change since the last interglacial period. Earth and Planetary Science Letters, 206, 253-271.

DOI : $10.1016 / \mathrm{s} 0012-821 \mathrm{x}(02) 01107-\mathrm{x}$

Durand-Delga M. (1995) - Etapes des interprétations géologiques et géodynamiques dans l'arc de Gibraltar. IV Coloquio International sobre el enlace fijo del estrecho de Gibraltar, Sevilla. SECEG, Madrid, 195-204.

El Abdellaoui J.E. (2014) - Evolution géomorphologique du littoral occidental de la péninsule tingitane (Maroc). Thèse de doctorat d'état, Université de Liège, Belgique, 204 p.

El Fahssi A. (1999) - Tectonique Alpine, Néotectonique et étude des formations marines quaternaire de la rive sud de Détroit de Gibraltar entre Tanger et Sebta (Rif-Maroc). Thèse de doctorat de troisième cycle, Université Mohammed V, Rabat, Maroc, $253 \mathrm{p}$.

El Gharbaoui A. (1977) - Note préliminaire sur l'évolution géomorphologique de la péninsule de Tanger. Bulletin de la Société Géologique de France, 19 (3), 615-622.

DOI : 10.2113 /gssgfbull.s7-xix.3.615

El Kadiri K., Sanz de Galdeano C., Pedrera A., Chalouan A., Galindo-Zaldívar J., Julià R., Akil M., Hlila R., Ahmamou M. (2010) - Eustatic and tectonic controls on 
Quaternary Ras Leona marine terraces (Strait ofGibraltar, northern Morocco). Quaternary Research, 74, 277-288.

DOI : 10.1016/j.yqres.2010.06.008

Fronval T., Jansen E., Haflidason H., Sejrup H.P. (1998) Variability in surface deep water conditiond in the nordic seas during the last interglacial period. Quaternary Science Reviews, 17, 963-985.

DOI : 10.1016/s0277-3791(98)00038-9

Gallup C.D., Lawrence Edwards R., Johnson R.G. (1994) The Timing of High Sea Levels Over the Past 200,000 Years. Science, 263, 796-800.

DOI : $10.1126 /$ science. 263.5148 .796

Gigout M. (1957) - Sur le Quaternaire marin au sud du Cap Spartel (Maroc septentrional). Comptes Rendus de l'Académie des Sciences, 244 (12), 1661-1663.

Hearty Paul J., Neumann A.C. (2001) - Rapid sea level and climate change at the close ofthe Last Interglaciation (MIS 5e) evidence from the Bahama Islands. Quaternary Science Reviews, 20, 1881-1895.

DOI : $10.1016 / \mathrm{s} 0277-3791(01) 00021-\mathrm{x}$

Hearty P.J., Hollin J.T., Neumann A.C., O'Leary M.J., McCulloch M. (2007) - Global sea-level fluctuations during the Last Interglaciation (MIS 5e). Quaternary Science Reviews, 26, 2090-2112.

DOI : 10.1016/j.quascirev.2007.06.019

Jedoui Y., Kallel N., Labeyrie L., Reyss J.L., Montacer M., Fontugne M. (2001) - Variabilité climatique rapide lors du dernier Interglaciaire (stade isotopique marin 5e), enregistrée dans les sédiments littoraux du Sud-Est tunisien. Earth and Planetary Sciences, 333, 733-740.

DOI : $10.1016 / \mathrm{s} 1251-8050(01) 01681-0$

Kidwell S.M. (1991) - The stratigraphy of shell concentrations. In Allison P.A., Briggs D.E.G. (Eds.), Taphonomy; Releasing the Data Locked in the Fossil Record. Plenum, New York, 211-290.

Kindler P., Davaud E., Strasser A. (1997) - Tyrrhenian coastal deposits from Sardinia (Italy): a petrographic record of high sea levels and shifting climate belts during the last interglacial (isotopic substage 5e). Palaeogeography, Palaeoclimatology, Palaeoecology, 133, 1-25.

DOI : 10.1016/s0031-0182(97)00028-x

Knudsen K.L., Seidenkrantz M.S., Kristensen P. (2002) - Last Interglacial and Early Glacial Circulation in the Northern North Atlantic Ocean. Quaternary Research, 58, 22-26. DOI : $10.1006 /$ qres.2002.2359

Kopp R.E., Simons F.J., Mitrovica J.X., Maloof A.C., Oppenheimer M. (2009) - Probabilistic assessment of sea level during the last interglacial stage. Nature, 462, 863-868.

Lecointre G. (1952) - Le Quaternaire de la zone internationale de Tanger. Notes Service Géologique du Maroc, 99, 109-113.

Lefèvre D., Raynal J.P. (2002) - Les formations plio-pléistocènes de Casablanca et la chronostratigraphie du Quaternaire marin du Maroc revisitées. Quaternaire, 13 (1), 9-21.

DOI : 10.3406/quate.2002.1700

Masson-Delmotte V., Buiron D., Ekaykin A., Frezzotti M., Gallée H., Jouzel J., Krinner G., Landais A., Motoyama H., Oerter H., Pol K., Pollard D., Ritz C., Schlosser E., Sime C., Sodemann H., Stenni B., Uemura R., Vimeux F. (2011) - A comparison of the present and last interglacial periods in six Antarctic ice cores. Climate of the Past, 7, 397-423.

DOI : 10.5194/cp-7-397-2011

Muhs D.R., Simmons K.R., Kennedy G.L., Rockwell T.K. (2002) - The last interglacial period on the Pacific Coast of
North America: Timing and paleoclimate. Geological Society of America Bulletin, 114 (5), 569-592.

DOI : 10.1130/0016-7606(2002)114<0569:tlipot>2.0.co;2

Occhietti S., Raynal J.P., Pichet P., Lefèvre D., Texier J.P. (1993) - Aminostratigraphie du dernier cycle climatique au Maroc Atlantique, de Casablanca à Tanger. Comptes rendus de l'Académie des Sciences, série II, 317, 1625-1632.

Occhietti S., Raynal J.P., Pichet P., Lefèvre D. (2002) Aminostratigraphie des formations littorales pléistocènes et holocènes de la région de Casablanca, Maroc. Quaternaire, 13 (1), 55-64.

DOI : 10.3406/quate.2002.1703

O'Leary M.J., Hearty P.J., Thompson W.G., Raymo M.E., Mitrovica J.X., Webster J.M. (2013) - Ice sheet collapse following a prolonged period of stable sea level during the last interglacial. Nature Geoscience, 6, 796-800.

DOI : $10.1038 /$ ngeo1890

Ozer A. (1989) - Signification des «lignes de galets» observées dans les dépôts quaternaires de la Sardaigne septentrionale. Geo-Eco-Trop, 11(1-4), 83-92.

Pedrera A., Ruiz-Constán A., Galindo-Zaldívar J., Chalouan A., Sanz de Galdeano C., Marín-Lechado C., Ruano P., Benmakhlouf M., Akil M., López-Garridoc.C., Chabli A., Ahmamou M., González-Castillo L. (2011) - Is there an active subduction beneath the Gibraltar orogenic arc? Constraints from Pliocene to present-day stress field. Journal of Geodynamics, 52, 83-96.

DOI : 10.1016/j.jog.2010.12.003

Rampnoux J.P., Angelier J., Colletta B., Fudral S., Guillemin M., Pierre G. (1977) - Les résultats de l'analyse structurale au Maroc. Bulletin de la Société Géologique de France, 19 (3), 594-599. DOI : 10.2113/gssgfbull.s7-xix.3.594

Rodriguez-Vidal J., Càceres L.M., Finlayson J.C, Gracia F.J., Martinez-Aquirre A. (2004) - Neotectonics and shoreline history of the rock of Gibraltar, southern Iberia. Quaternary Science Reviews, 23, 2017-2029.

DOI : 10.1016/j.quascirev.2004.02.008

Rohling E.J., Grant K., Hemleben Ch., Siddall M., Hoogakker B.A.A., Bolshaw M., Kucera M. (2008) - High rates of sea-level rise during the last interglacial period. Nature Geoscience, 1, 38-42.

DOI : 10.1038/ngeo.2007.28

Schellmann G., Radtke U., Potter E.K, Esat T.M., McCulloch M.T. (2004) - Comparison of ESR and TIMS U/Th dating of marine isotope stage (MIS) 5e, 5c, and 5a coral from Barbados implications for palaeo sea-level changes in the Caribbean. Quaternary International, 120, 41-50.

DOI : 10.1016/j.quaint.2004.01.005

Silva P.G., Goy J.L., Zazo C., Bardaji T., Lario J., Somoza L., Luque L., González-Hernández F.M. (2006) - Neotectonic fault mapping at the Gibraltar Strait Tunnel area, Bolonia Bay (South Spain). Engineering Geology, 84, 31-47. DOI : $10.1016 /$ j.enggeo.2005.10.007

Speed R.C., Cheng H. (2004) - Barbados Evolution of marine terraces and sea level in the last interglacial, Cave Hill. Geological Society of America Bulletin, 116 (1-2), 219-232. DOI : $10.1130 / \mathrm{b} 25167.1$

Stearns C.E., Thurber D.L. (1965) $-{ }^{230} \mathrm{Th}-{ }^{234} \mathrm{U}$ dates of late Pleistocene marine fossils from the Mediterranean and Moroccan littorals. Quaternaria, 7, 29-42. 
Stirling C.H., Esat T.M., Lambeck K., McCulloch M.T. (1998) - Timing and duration of the Last Interglacial: evidence for a restricted interval of widespread coral reef growth. Earth and Planetary Science Letters, 160, 745-762. DOI : $10.1016 / \mathrm{s} 0012-821 \mathrm{x}(98) 00125-3$

Van Nieuwenhove N., Bauch H.A., Eynaud F., Kandiano E, Cortijo E., Turon J.L. (2011) - Evidence for delayed poleward expansion of North Atlantic surface waters during the last interglacial (MIS 5e). Quaternary Science Reviews, 30, 934-946. DOI : 10.1016/j.quascirev.2011.01.013

Williams A.H., Walkden G.M. (2002) - Late Quaternary highstand deposits of the southern Arabian Gulf: a record of sea-level and climate change. Geological Society, London, Special Publication, 195, 371-386.

DOI : 10.1144/GSL.SP.2002.195.01.20

Zazo C., Goy J.L., Dabrio C.J., Bardaji T., Hillaire-Marcel C., Ghaleb B., González-Delgado J.A., Soler V. (2003) - Pleistocene raised marine terraces of the Spanish Mediterranean and Atlantic coasts: records of coastal uplift, sea-level highstands and climate changes. Marine Geology, 194, 103-133.

DOI : $10.1016 / \mathrm{s} 0025-3227(02) 00701-6$
Zazo C., Goy J.L., Hillaire-Marcel C., Dabrio C.J. González-Delgado J.A., Cabero A., Bardaji T., Ghaleb B., Soler V. (2010) - Sea level changes during the last and present interglacials in Sal Island (Cape Verde archipelago). Global and Planetary Change, 72, 302-317.

DOI : 10.1016/j.gloplacha.2010.01.006

Zazo C., Silva P.G., Goy J.L., Hillaire-Marcel C., Ghaleb B., Lario J., Bardaji T., González A. (1999) - Coastal uplift in continental collision plate boundaries: data from the Last Interglacial marine terraces of the Gibraltar Strait area (south Spain). Tectonophysics, 301, 95-109.

DOI : 10.1016/s0040-1951(98)00217-0

Zecchin M. (2007) - The architectural variability of small-scale cycles in shelf and ramp clastic systems: The controlling factors. Earth-Science Reviews, 84, 21-55. DOI : 10.1016/j.earscirev.2007.05.003

Zecchin M., Civile D., Caffau M., Roda C. (2009) - Facies and cycle architecture of a Pleistocene marine terrace (Crotone, southern Italy): A sedimentary response to late Quaternary, high-frequency glacio-eustatic changes. Sedimentary Geology, 216, 138-157.

DOI : $10.1016 /$ j.sedgeo.2009.03.004

\section{Version française abrégée}

Ce travail apporte des éléments nouveaux sur les fluctuations du niveau marin au centre de la rive sud du détroit de Gibraltar au cours $d u$ sous-stade isotopique $5 e d u$ dernier interglaciaire en précisant le contexte géomorphologique et la stratigraphie des coupes de référence, stratigraphies qui seront appuyées par des datations isotopiques.

L'étude concerne trois terrasses marines observées sur la côte sud du détroit de Gibraltar, d'est en ouest : la terrasse de Zhâra, la terrasse de Dhâda et la terrasse de Hejar-Lasfar (fig. 2b). Les coupes présentent une puissance totale variant de 3 à $6 \mathrm{~m}$. La macrofaune est formée principalement par des algues, des anthozoaires (coraux), des crustacés, des échinodermes, des gastéropodes et des lamellibranches (Tableau 2). Les trois terrasses reposent en discordance sur le substratum. La limite inférieure des séquences est une surface d'abrasion marine dont la formation a été fort contrôlée par la lithologie et la structure du substratum.

Les trois terrasses étudiées, montrent toutes six unités de faciès distincts qui sont bien corrélées (fig. 15). L'unité U1 est formée par un conglomérat de base à matrice calcaire et à coquilles dispersées caractéristique d'une charge sédimentaire transgressive (Kidwell, 1991; Cattaneo et Steel, 2003; Catuneanu, 2002; Catuneanu et al., 2009; Zecchin et al., 2009). Elle représente la première pulsation transgressive dont l'âge se situe fort probablement entre 125 et 128 kyr. Sur les trois coupes étudiées, l'unité U2 se présente sous forme d'une calcarénite massive à grains moyens dont l'épaisseur varie de 0,15 à 0,5 m (fig. 15). L'épaisseur limitée de celle-ci suggère une phase régressive forcée de courte durée. À Dhâda et à Hejar-Lasfar, l'unité U3 est formée par des galets roulés emballés dans une matrice de sables carbonatés riches en fossiles (fig. 15). À Zhâra, celle-ci est formée par un poudingue à matrice carbonatée (fig. 15). Dans les trois coupes, l'unité U3 possède toutes les caractéristiques sédimentaires d'une phase transgressive confirmée par la concentration en restes d'une macrofaune variée (Tableau 2) (Kidwell, 1991; Cattaneo et Steel 2003; Zecchin, 2007; Zecchin et al., 2009; Andreucci et al., 2009). Cette accumulation témoigne de la redistribution des coquilles sous l'action des courants (Kidwell, 1991 ; Zecchin, 2007). Quatre datations isotopiques U/Th ont été réalisées sur du corail Dendrophyllia ramea (Linné) (Tableau 3). Elles livrent un âge minimal de 119,6 kyr.
La seconde phase transgressive cède la place progressivement à la deuxième et dernière phase régressive. Cette dernière constitue $80 \%$ de l'épaisseur totale de la série (de U4 à U6) (fig. 15). Cette dissymétrie entre l'épaisseur des dépôts transgressifs et la régression finale rappelle le cycle de type régressif «R» de la typologie des systèmes de sédimentation clastique proposée par Zecchin (2007) et Zecchin et al. (2009). Cette architecture est commune aux successions marines pléistocènes, contrôlées par des changements glacio-eustatiques de haute amplitude. Une augmentation rapide du niveau de base favorise l'accumulation de niveaux transgressifs relativement minces (Zecchin, 2007 ; Zecchin et al., 2009). L'unité U6 marque le retrait définitif des eaux marines. Elle est caractérisée par l'abondance de gastéropodes terrestres dans du sable éolien.

À l'échelle locale, les auteurs estiment que le niveau de la mer durant le MIS 5e a été situé à 5-6 m (Zazo et al. 1999 et 2003 ; Rodriguez-Vidal et al., 2004; El Kadiri et al., 2010; Stearns and Thurber, 1965; Brébion et al., 1986; Alouane, 1997; El Abdellaoui, 2014; Occhietti et al., 1993 et 2002 et Lefèvre et Raynal, 2002). À partir du dernier interglaciaire, la partie centrale de l'arc de Gibraltar montre un soulèvement. En effet, entre la ville de Tanger et Ras-Ciress (fig. 1B), le soulèvement du paléorivage est de 8 à $20 \mathrm{~m}$ NGM (Cadet et al., 1977 ; El Gharbaoui, 1977 ; El Fahssi, 1999). De l'autre côté du détroit de Gibraltar au sud de l'Espagne, le soulèvement est de 5 à $20 \mathrm{~m}$ NG M entre Zahara à l'ouest et le rocher de Gibraltar à l'est (fig. 1) (Zazo et al., 1999, Rodriguez-Vidal et al., 2004).

L'analyse chronostratigraphique et tectonique la rive sud $d u$ détroit de Gibraltar montre deux pulsations transgressives d'origine eustatique au cours du sous-stade isotopique 5e. La zone centrale a été soulevée avec un taux moyen de 0,085 mm/an au cours des 117 kyr. Elle a été portée à une altitude de 13 à $16 \mathrm{~m}$ par rapport au niveau actuel de la mer. Le soulèvement a eu lieu fort probablement après la mise en place de l'ensemble de la série. La rive nord du détroit de Gibraltar a été soulevée avec un taux moyen global de 0,10 $\mathrm{mm} /$ an (Zazo et al., 1999). La différence entre les taux de soulèvement des deux rives, est fort probablement due à la distribution des champs de contraintes qui ont été relativement plus forts sur la rive nord du détroit de Gibraltar. 